\title{
PUBLIC OPINION TOWARDS PROVINCIAL POWERS OVER MUNICIPALITIES:THE CASE OF TORONTO
}

\author{
by \\ Michal Zhitomirsky
}

Arts and Science and Economics BASc

McMaster University, 2018

A Major Research Paper presented to Ryerson University

in partial fulfillment of the

requirements for the degree of

Master of Arts

in the program of

Public Policy and Administration

Toronto, Ontario, Canada, 2019

(C) Michal Zhitomirsky, 2019 


\section{Author's Declaration}

I hereby declare that I am the sole author of this MRP. This is a true copy of the MRP, including any required final revisions.

I authorize Ryerson University to lend this MRP to other institutions or individuals for the purpose of scholarly research.

I further authorize Ryerson University to reproduce this MRP by photocopying or by other means, in total or in part, at the request of other institutions or individuals for the purpose of scholarly research.

I understand that my MRP may be made electronically available to the public. 


\title{
PUBLIC OPINION TOWARDS PROVINCIAL POWERS OVER MUNICIPALITIES:THE CASE OF TORONTO
}

\author{
by \\ Michal Zhitomirsky \\ Master of Arts \\ Public Policy and Administration \\ Ryerson University \\ Toronto, Ontario, Canada, 2019
}

\begin{abstract}
:
This paper will analyze the case of redistricting in Toronto using data collected from the 2018 Canadian Municipal Election Study (CMES, n.d). The analysis will explore Torontonian public opinion using multivariate regression analysis in the following areas: support for provincial control over municipal matters in general, and support for the provincially imposed ward redistricting in 2018. Specifically, five central hypotheses will be tested through a series of ordered logistic regression models to determine the correlates of support for the exercise of provincial powers over municipalities and support for such powers using the recent redistricting in Toronto as a case study.
\end{abstract}




\section{Table of Contents}

Abstract iii

List of Tables $\quad$ vi

List of Figures ni vi vi vis

1. Introduction and Literature Review 1

A. Literature Review Municipalities and the Constitutional Division of Powers 5

B. Federal-Municipal and Tripartite Relations 12

C. Provincial-Municipal Relations 16

2. Provincially Imposed Changes to Municipalities 18

$\begin{array}{ll}\text { A. Downloading } & 18\end{array}$

B. Shifting Transfers 20

C. Amalgamations $\quad 22$

D. Restructuring in Winnipeg 22

E. Restructuring in Montreal 23

F. Restructuring in Ottawa 24

G. Restructuring in Toronto $\quad 26$

H. Recent Restructuring Events Toronto 28

3. Public Opinion 32

A. Why Should the Government Be Responsive? 32

B. Is the Government Responsive to Public Opinion? 33

C. Background on Public Consultation 36

D. How does Federalism Impact Government Responsiveness? 37

4. Research Questions 39

Hypothesis $1 \quad 39$

Hypothesis $2 \quad 41$

Hypothesis $3 \quad 42$

Hypothesis $4 \quad 43$

Hypothesis $5 \quad 44$

5. Data 45

A. Key Variables $\quad 45$

B. Dependent Variables $\quad 45$

C. Independent Variables (Theoretical) 46

C. Control Variables $\quad 47$

D. The Type of Analysis $\quad 48$

$\begin{array}{ll}\text { 6. Results } & 50\end{array}$ 
7. Conclusion

Appendix

References 


\section{List of Tables}

Table 1: Support for Council Size Reduction and Unilateral Provincial Government Intervention

\section{List of Figures}

Figure 1: Distribution of Outcome Variables 


\section{INTRODUCTION AND LITERATURE REVIEW}

In 2018, Ontario Premier Doug Ford passed the Better Local Government Act (Bill 5) to

reduce the size of Toronto City Council from 47 to 25 wards, aligning municipal wards with provincial ridings (Keenan 2018). While the Premier promoted Bill 5 as a cost-saving measure, he was accused of gerrymandering, reducing effective representation, and stifling local democracy (Keenan 2018; Pagliaro 2018). This change was made without input from the City itself.

The question of Toronto's sovereignty over its own governmental structure is significant given the size and importance of Toronto to Canada. Although some analysts argue, citing s92(8) of the Constitution Act, that cities are not governments, but rather administrative units of their respective provincial government, this analysis assumes that Toronto is a government and deserves to be treated as such. As the fourth largest city in North America, Toronto not only has international status, but is also a dominant national player as its economy represents a greater share of national GDP than the 6 smallest Canadian provinces and is nearly on par with larger provinces such as Quebec and Alberta (Yalnizyan 2018). Due to the city's growing domestic and global significance, it is important to address the issue of municipal-provincial relations using current data and to consider public perceptions of the powers that the Canadian Constitution affords provinces over its municipalities.

The purpose of this major research paper is to examine public opinion towards the exercise of provincial powers over municipalities more broadly, and to specifically identify the correlates of support for such powers using the recent redistricting in Toronto and survey data from the Toronto 2018 municipal election as a case study. This question will be addressed through a multivariate regression analysis of Torontonians' attitudes in the following areas: 
support for provincial control over municipal matters in general, and support for the provincially imposed ward redistricting in 2018. This paper will also provide commentary on whether there is congruence between opinions on these two matters.

The investigation of people's attitudes towards redistricting has important policy implications. Prior to 2018, Toronto had a 44 ward system, but to accommodate population growth, this was set to increase by three seats in 2018. In the proposed 47 ward model, it has been argued that the 3 additional seats would have privileged left-leaning downtown voters, perhaps altering balance on council (Oved 2018). Meanwhile, the 25-ward structure is thought to confer an advantage to suburban voters, who tend to be more Conservative leaning. While it is important to note that municipal elections are technically non-partisan, opinion poll data from 2014 show that voters associate candidates with political parties and ideologies (McGregor et al., 2016). As such, it is relevant to investigate how partisan preferences are correlated with support for provincial control and the redistricting decision.

Public opinion on this matter is significant because government responsiveness is an essential feature of a representative democracy (Tausanovitch and Warshaw, 2014, pg.3; Achen 1978; see section 3A for further details). Governments maintain their legitimacy by creating policies that reflect the wishes of the people they govern. It is therefore important to know whether citizens support redistricting, and provincial powers more broadly, and also to determine the characteristics of these individuals. It is especially valuable to understand the types of individuals who oppose or support certain policies, given that this investigation can reveal whether the government imposes changes that are opposed by minority groups or vulnerable populations. Indeed, another important feature of a democracy is equal representation. If the 
government ignores certain disadvantaged groups, this would indicate a lack of equal representation.

This paper will begin with a comprehensive literature review. This review will begin by providing important context about municipal-provincial relations in Canada. It is important to understand the power imbalances between the levels of government and how these relationships have historically operated. This background information will help explain why Toronto was subject to redistricting and the policy tools (or lack thereof) available to the city to resist the change. This review will begin by providing important context about municipal-provincial relations in Canada. It will include a basic introduction to the role of municipalities in Canadian intergovernmental relations, discuss changes made to municipalities over time, highlight the current redistricting case study, make note of the importance of public opinion, and conclude with a discussion of government responsiveness to that opinion.

Next, the paper moves on to data analysis, in order to provide some practical insight into these matters, as they apply to the case of redistricting in Toronto. The analysis section of this paper will explore Torontonians' attitudes by using the data collected from the 2018 Canadian Municipal Election Study (CMES, n.d), which includes a representative sample size of 2,400 Toronto residents. Respondents were asked survey questions which directly relate to this work's central research questions: whether they think it is a good thing that Toronto City Council has been reduced from 47 to 25 councillors and whether the government of Ontario should have the power to unilaterally make changes to Toronto's municipal government.

It is also important to compare and contrast public opinion data about support for redistricting and provincial control over municipal matters. Considering public opinion towards 
redistricting as an indicator of whether people are happy with provincial interference in municipal matters is misleading. For example, if citizens are in favour of provincial interference in municipal matters, it does not necessarily mean they will be in favour of this particular redistricting decision. It may, for example, be the case that respondents want provincial control, but lacked adequate channels to express policy preferences due to the absence of public consultations about the redistricting decision. Or, it may be the case that respondents did not want provincial control but still support this particular redistricting decision.

In all, this paper will highlight the importance of representative and democratic local governance, and to what extent it is undermined by unilateral actions at higher levels of government. This research will serve as a unique contribution to a body of literature about how citizens preferences are translated into policies within federations, and how the federal structure can mute or bolster certain voices. The analysis will reveal which demographics are most opposed to and which are most in favour of unilateral changes in local government and how certain groups form their opinions about policies. Not only will this research contribute to Canadian literature about representative democracy, but will also provide useful information for local campaign management. For example, one of the paper's findings is that partisan preferences play a significant role in informing citizen's policy opinions. Overall, this paper will contribute to the limited literature on Toronto in a number of significant areas, including implications for local campaigns and, more broadly, the legitimacy and strength of civic democracy in Canada. 


\section{A. Literature Review Municipalities and the Constitutional Division of Powers}

In order to contextualize the Toronto case study, it is first important to understand how the powers of the two constitutionally entrenched levels of government affect municipalities. The purpose of this section is to explore the constitutional division of powers and the relationships between the different levels of government in order to understand how the legal and informal relationships affect municipal governance. A discussion of the constitutional division of powers will serve as the foundation for understanding the following sections, revealing how it was possible for the province to unilaterally redistrict Toronto.

Canada is one of 30 nations that has a federal as opposed to a unitary government (Inwood, 2013, p. 6) and a system of government that concentrates power in the executive branch among the Prime Minister, Cabinet in Ottawa, and provincial premiers (Simeon, 2002, p. 400; Mallory, 1981, p.231). Another feature of Canada's federal system is that it is defined both by the British North America Act (BNA) and unwritten conventions informed by the British-style parliamentary government (Sharman, 1984, p. 1; Mintz et al., 2019, p.289; Meekison et at al,, 2004, p.16; Inwood et al., 2011, p.289). Aside from the unwritten conventions, the Canadian Constitution is composed of several written documents which describe the division of powers and how they are connected with citizens' rights: the BNA of 1867, the Constitution Act of 1982, and the Charter of Rights and Freedoms (Inwood, 2013, p. 9).

Of greatest relevance of these components of the Constitution are Sections 91 and 92 of the BNA Act, which lists the powers that are divided between the federal and provincial governments. Provinces were assigned the areas of welfare, health, and education because the federal government assumed these responsibilities would be of least importance (Inwood, 2013, 
p. 56; Bastien, 1979, p.1). Meanwhile, the federal government was given power over trade and commerce, fisheries, interprovincial transportation and communication, the postal service, and primary authority over building a railway between Montreal and Halifax (Inwood, 2013, p.50). Not only did the BNA Act create these divisions between policy areas, but it also made important financial distinctions wherein it formally limited the provinces' abilities to raise money (Inwood, 2013, p.50). Most importantly, it gave the federal government the power to generate revenue "by any Mode or System of Taxation" (s.92.2) while the provinces could only do so through "direct taxation" (s.92.2) and through royalties on provincially owned national resources (s.109).

It is also important to examine the division of powers by looking at both the formal and informal governance mechanisms. In the first few decades following 1867, the federal government "vigorously exercised" its powers to disallow provincial acts (Simeon and Papillon 2006; Bélanger 2001). The federal government also has the power to intervene in areas of provincial jurisdiction because the Constitution Act of 1867 allows the federal govern to "make laws for the Peace, Order and good Government of Canada" which transcend jurisdictional boundaries (Simeon and Papillon 2006). It is important to note that there is 150 years of jurisprudence defining the limits of both the "Peace Order and Good Government" provision and the "Property and Civil Rights" provision. However, some scholars argue that this provision is not necessarily threatening to provincial autonomy because it is followed by a restrictive clause that stipulates the federal government has the authority to do so only "in relation to all Matters not coming within the classes of Subjects by this Act assigned exclusively to the Legislatures of the Provinces" (Pigeon, 1951, p.1128). Some scholars believe that the federal and provincial governments both have equally permissive powers to interfere across jurisdictional spheres but 
not territory. While the federal government has the power to enact laws for the "peace, order, and good government of Canada," the provinces also have power over "property and civil rights" which widens their jurisdiction (Simeon, 2002, p.405). Simeon (2002) argues that if "any government feels compelled to intervene in a specific area, it can usually find some head of power in the constitution that can justify it" (Simeon, 2002, p.405). It is important to note that Simeon is referring to constitutionally entrenched levels of government given that the provinces have jurisdiction over "local works and undertakings," which allows them to unilaterally enact municipal-level laws (Simeon, 2002, p. 405). Meanwhile, municipalities have responsibilities that are entirely defined by the provinces and do not have jurisdiction outside their sphere of influence. These responsibilities can also be changed unilaterally, by the provinces themselves either through "common ordinances" like the Municipal Act, or through municipality-specific legislation like the City of Toronto Act.

Indeed, some argue that the British North America Act (1867) designated local government to fall under provincial jurisdiction with the purpose of establishing a highly centralized federal state (Stevenson, 2004, p.6; Scott, 1951, p.1095-1096; Bastien, 1979, p.1). While some scholars contend that Canada was originally envisioned as a centralized federation (Stevenson, 2004, p.6; Field, 1992, p.107), others argue that Quebec viewed Confederation as a decentralizing force that would help them gain autonomy for French-speaking Canadians and avoid control of the English majority (Simeon, 2002, p.400). Another argument is that the importance of policy areas has shifted, leaving the provinces with a high level of influence over the most important policy domains (Simeon, 2002, p. 398). The notion that provinces have such strong powers over municipalities would seemingly fit with the idea of a decentralized 
federation, particularly in light of the fact that Canadian municipalities have become so large an important to the country.

Regardless of the original intention or perception of the Constitution Act of 1867, the power of provinces vis-a-vis the federal government has fluctuated over time. Following World Wars I and II, the provincial governments pursued peacetime priority areas that fell under their purview, including social welfare (Bastien,1979 p.4). The dominant "watertight compartment" approach - which was the federal government's attempt to strictly limit the distribution of powers by reducing the possibility of shared legislative jurisdiction - was replaced by the development of jointly financed and administered programs between the two constitutionally entrenched governments in areas of provincial jurisdiction (Macdonald, 2012, p.56; Mallory, 1981, p. 233). While the provinces originally had control over the area of social welfare, the aftermath of WWII left the provinces without the fiscal means to sustain expanding social programs, causing them to rely on finances from the federal government to create a Canada-wide welfare system (Simeon and Papillon 2006). However, this encroachment was not viewed negatively, at least by most English-speaking Canadians who saw the expansion of the welfare state as a nation-building exercise (Triolo, 2013,p.407; Simeon and Papillon 2006). This idea did not resonate as strongly in Quebec which experienced "competing ideas of nationality" (Simeon and Papillon 2006).

The advent of these post-war common programs and standards helped breach constitutional barriers, in addition to the creation of First Minister's Conferences which are meetings that include the Prime Minister and Premiers, with no representation from the third order of government (Mallory, 1981, p.233). The greater negotiating powers of the provinces 
arose largely due to their development of bureaucratic capacity that was initially necessarily to manage programs at the level of federal standards; meanwhile, municipalities had limited opportunities to develop this infrastructure (Mallory, 1981, p.233). Finally, events like the economic crisis of the 1930s saw weakened provincial power, though this was only temporary, as the 1940s saw the federal government transfer control of the gasoline tax and sales tax on electricity and gas to the provinces (Bastien, 1979, p.4).

While practices have evolved over time and with changing circumstances, questions of jurisdiction for the two constitutionally entrenched levels of government can be clarified by sections of the Constitution that define the key divisions of powers, which primarily include 91 and 92, and also include the following: 93, 94, 95, 101, 117, and 132 (Inwood, 2013, p. 9). Meanwhile, municipal institutions are merely listed as provincial responsibilities under the BNA and 1982 Constitution — thus leading them to be called "creatures of the province". This is despite the fact that local governments are responsible for the delivery of many important services (Slack, 2009, p.2; Simeon and Papillon 2006; FCM, 2013, p.7).

Municipalities were originally created as an instrument for service delivery and as means of fulfilling provincial objectives (Lazar and Seal, 2005, p.28). As noted above, in Section 92(8) of Canada's Constitution, municipal institutions under fall under the jurisdiction of provincial governments (Lazar and Seal, 2005, p.28). From a constitutional perspective, local governments are defined by provincial statues and provinces each have their own unique legislation which defines the powers and responsibilities of municipal governments (Lazar and Seal, 2005, p.28). Ultimately, provinces have the ability to create, amalgamate, and disband local governments (Spicer, 2015, p.46; Sancton 1993; Siegel 1997). 
The autonomy of the province to define municipal responsibilities has led to a diverse patchwork of municipal responsibilities across the provinces (Lazar and Seal, 2005, p.28). For example, the provincial government in New Brunswick is responsible for service delivery in low-populated areas within its borders, rather than a municipal body. In contrast, Quebec has overlapping jurisdictions where local communities/city-regions fall under the purview of multiple municipal levels (Lazar and Seal, 2005, p.29). Ontario is also unique from other provinces given that its cities play a larger role in social service provision than do cities outside Ontario.

As creatures of the province, city boundaries, powers, means of generating revenue, and method of election are all determined by provincial governments (Simeon, 2002, p. 404; Lazar and Seal, 2005, p.28). Provinces have delegated the responsibility of many important services to cities, including roads and public transit, police and fire protection, waste and recycling management, water and sewers, and recreation (Slack, 2009, p.3; Simeon and Papillon 2006). In recent years, these responsibilities have often increased due to "downloading" from the provinces, wherein municipalities are tasked with greater responsibilities related to affordable housing and welfare (Simeon and Papillon 2006). Despite the increase in service delivery responsibilities, funding or the means to generate funding, have not risen to an equivalent degree and cities still remain under tight provincial control (Slack, 2009, p.2; Bird \& Tassonyi, 2003).

Cities have limited access to major revenue streams which are defined by the provinces under section 92(9) of the Constitution (which refers only to license revenue), including property taxes and user fees, and are subject to conditional provincial transfers (Slack and Bird, 2003, p. 72; Slack, 2009, p.2; Côté, and Fenn, M, 2014, p.6; Courchene, 2007, p.19; Lazar and Seal, 
2005, p.28). To this day, provinces have authority to establish and rearrange municipal boundaries, mandate and set standards for municipal services, and require municipalities to balance budgets while severely limiting their fiscal autonomy (Slack, 2009, p.2; Côté, and Fenn, M, 2014, p.6; Slack and Bird, 2003, p.73). While provinces can delegate revenue streams to municipalities at their discretion, it has to be in alignment with legislation which can be repealed by legislation.

It is important to note that some municipalities have greater financial autonomy than others, and each province has its own unique Municipal or Local Government Acts (Slack, 2009, p.3). Some cities have Charters that award them greater autonomy in some areas: Toronto, Vancouver, Saint John's, Winnipeg, and Montreal. For example, Toronto is able to generate revenue with tools other than the property tax - including the alcohol, entertainment, tobacco, and land transfer taxes - as listed under the City of Toronto Act ${ }^{1}$ (Slack, 2009, p.3). Indeed, the Municipal Act of 2001 and the City of Toronto Act in 2006 fundamentally reshaped Toronto's and Ontario's relationships by granting new taxation powers to the city (Côté, and Fenn, 2014, p.14). Another unique feature of Toronto is that it shares costs for social services with Ontario, which is not the case for municipalities in the rest of the provinces (Slack, 2009, p.4). In 2007, social services across Canada represented approximately $9 \%$ of total municipal spending. If the data from Ontario are omitted, this figure drops to $1 \%$ (Slack, 2009, p.4).

The current financial structure for municipalities may have been suitable for Canadian cities in 1867 , where 3.2 million individuals lived in Canada and $84 \%$ of those individuals lived in rural areas (Statistics Canada 2018). While the economy at the time relied on agriculture and

\footnotetext{
${ }^{1}$ Please note that the City of Toronto Act is a piece of provincial legislation that sets out Toronto-specific
} differences from the "common ordinance" that is the Municipal Act. 
natural resource extraction, demographic and economic shifts have increased the importance of urban areas as centres of productivity and economic engines. In 2011, less than $18.9 \%$ of the population lived in rural areas, and in 2014 nearly $70 \%$ of individuals were living in census metropolitan areas (Statistics Canada 2015; Statistics Canada 2018). In 2014, Montreal, Vancouver and Toronto housed 35\% of the country's entire population (Statistics Canada 2015). In 2016, the Toronto census metropolitan area (CMA) (which includes the Greater Toronto Area) was Canada's biggest CMA, with a population of 5,928,040. This number represents a $6.2 \%$ increase from 2011 (Statistics Canada 2017). Overall, 82\% of Canadians live in large and medium-sized cities (Press 2017). As such, local service delivery is an important issue on the agenda given that Canadians rely on municipal services and cities are drivers of economic prosperity (Slack and Bird, 2003, p.74). The following section will describe how this important level of government interacts with the federal and provincial levels.

\section{B. Federal-Municipal and Tripartite Relations}

Before narrowing in on the topic of provincial-municipal relations, it is first important to contextualize this relationship by understanding how it compares to tripartite and federalmunicipal dynamics (given that municipalities engage with both levels of government). This discussion is significant considering that municipalities need to work with other levels of government to meet service delivery and policy goals. Since confederation, industrialization, residential and commercial development, and the boom in immigration have put additional pressure on municipalities to increase infrastructure and service delivery in response to the growing population (Côté, and Fenn, 2014, p.6). However, these objectives became particularly difficult to achieve in the 1930s when municipalities began to face debt and default concerns- 
which was only compounded by the pressures of additional welfare expenditures that doubled between 1926 and 1937 to accommodate the economic pressures caused by the depression (Tassonyi 1994; Côté, and Fenn, 2014, p.6). Problems continued into the 1950s and 1960s, when spikes in population growth created an expansion of responsibilities for cities while they lacked sufficient means to raise revenue given their primary reliance on property taxes (Smith 1967; Côté, and Fenn, 2014, p.8). In response to the demand for greater municipal autonomy, Ontario established the Provincial-Municipal Liaison Committee to allow for discussion between governments; however, it was soon discontinued and was not replaced by a robust intergovernmental institution for municipalities (Côté, and Fenn, M, 2014, p.8). The weak intergovernmental institutional framework makes it difficult for cities to collaborate with other levels of government on municipal policy and service delivery projects.

There are several examples to suggest that municipalities have generally enjoyed a collaborative relationship with the federal government, as compared to the one-sided nature of the provincial-municipal relationship. To deal with Canada's post-war housing crisis, the Canada Mortgage and Housing Corporation (1946) became an important body for municipal-provincialfederal cooperation, and remained so into the 1970s (Stoney et al., 2009, p.377; Cote and Fenn page 8). In 1971, the Ministry of State and Urban Affairs was created by the federal government to facilitate the federal-municipal relationship. However the MSUA was short-lived and was dissolved in 1978 (Dewing et al., 2006; Côté, and Fenn, M, 2014, p.8; Spicer, 2011, p.123; FCM, 2012, p.1). There was some responsive action taken by the federal government and provincial governments between 1968 and 1973 by increasing transfer payments by $102 \%$. However, this initiative ultimately failed to provide municipalities with financial independence since these 
grants were conditional (O'Brien 1975; Côté, and Fenn, 2014, p.8).

The MSUA was significant because it coordinated federal policy across governments, funded projects identified by urban communities, and eventually entered into those projects as a leadership partner rather than solely as a funder (Spicer, 2011, p.123). It was an attempt to coordinate policy across federal departments using an urban perspective (Stoney et al., 2009, p. 391). In its final years of activity before its dissolution in 1978, the MSUA entered into direct relationships with municipalities without having to liaise with provincial governments. The ministry was dissolved when the provinces exercised their veto power as they believed the ministry was encroaching on their jurisdiction (Spicer, 2011, p.123). While there is mounting support among municipalities to have a stronger relationship with the federal government, provinces have a strong resistance to this idea and there is no formal constitutional link between the federal and municipal government (Simeon and Papillon 2006; Simeon, 2002, p. 398; Sancton 2002; FCM, 2012, p.1; Steylter, 2005, p.8).

Difficulties persisted into the late 1990s and early 2000s when the Ontario government undertook amalgamation, reformed the property tax system, and realigned responsibilities between provincial and municipal sectors (Côté, and Fenn, M, 2014, p.10). All of this placed a heavy strain on municipalities. In response to this, in the early 2000s, the "New Deal" emerged as the federal priority, which was an initiative to promote tripartite government coordination to develop sustainable strategies for improving local communities. The 2005 budget included several commitments such as providing cities with a portion of the gas tax revenues; renewing infrastructure programs; and raising contributions to Green Municipal Funds (Department of Finance 2005). These commitments were reduced in 2006 when the government changed from 
Liberal to Conservative (Côté, and Fenn, M, 2014, p.13; Bradford, 2007, p.8; Stoney et al., 2009, p. 392). Some scholars suggest the reason for the abandonment of the New Deal priorities was due to the perception that it was merely a way to improve the ratings of the Liberal party in cities since urban voters tend to support Liberals over Conservatives (Stoney et al., 2009, p. 375).

After the change in government, the Conservatives indicated that they wanted to merely maintain a federal-urban presence in cities (Bradford, 2007, pg.1). The Conservative government's goals departed from those of the Liberals, showing a focus on remedying the fiscal imbalance within federalism (Bradford, 2007, pg.11). Another prominent priority was a focus on reducing gun violence through federal sentencing reform, but with no other investigation into trilevel policy coordination as promised in the New Deal (Bradford, 2007, pg.11). In all, the Conservatives continued with the gas tax and investments in urban infrastructure, but with no further initiatives.

Indeed, while there have been extended periods of federal-municipal cooperation, as is the case with the municipal-provincial relationship, municipalities appear to be largely at the mercy of federal governments. Nevertheless, there were some long-lasting positive impacts of the New Deal in 2004, and it represented a significant attempt at federal-municipal cooperation. Cities were promised that municipal representatives would be welcome at federal budget meetings, as part of a broader commitment to allow cities to have a greater impact on shaping federal policies that have direct urban implications (Courchene, 2006, p.101). The federal government also agreed to share a portion of its gasoline tax with both large and small cities, promising $\$ 5$ billion over 5 years to help provide a consistent source of funding that would be distributed through bilateral agreements with provincial governments (Courchene, 2006, p.102; 
Berdahl, 2006, p.41). The Paul Martin government also promised a $100 \%$ GST rebate to municipalities in the 2004 federal budget (Berdahl, 2006, p.41). The 2008 federal budget made the Gas Tax Fund permanent and also committed $\$ 500$ million for public transit infrastructure improvement (FCM, 2013, p.12). While the 2008/2009 financial crisis set back municipalities in their desired funding goals, the 2013 budget included a 10 -year $\$ 47$ billion commitment to improve local infrastructure and it also indexed the Gas Tax Fund which was a response to a longstanding municipal concern (FCM, 2013, p. 13). After considering the complex federalurban relationship, this paper now turns to a discussion of the provincial-municipal relationship.

\section{Provincial-Municipal Relations}

Despite the long history of federal-municipal interactions, the most important relationship that municipalities have with another level of government is with the provincial government. As previously suggested, this relationship sees municipalities as largely subordinate to their provincial masters. The next section of this literature outlines a great deal of evidence of this claim. Prior to doing so, however, it is worth nothing that, despite the control that provinces exercise over municipalities, cities have challenged this inferior role, and have secured some concessions. For example, since 2003, the Ontario government has increased infrastructure investments, and increased its share of public health costs from 50\% to 75\% (MMAH, 2011, p.

2). In 2004, British Colombia uploaded responsibilities for recycling and waste management to reduce the administrative and financial burden on municipalities (EPR 2018). Despite some examples of cooperation, these events do not represent a uniform paradigm shift to a more cooperative framework (MMAH, 2011, p.2). 
While it is true that cities do sometimes have clout, this situation is the exception rather than the rule. The Ontario Local Services Realignment strategy of the 1990s- which downloaded responsibilities to municipalities including public transit, child care, ambulance services, and social housing - had lasting effects in many Ontario municipalities which contributes to a continuing trend that municipalities are still not seen as equal partners with the constitutionally entrenched levels of government. A major municipal concern with both federal and provincial relations is that cooperation and interference occur on an ad-hoc basis (FCM, 2013, p.24). This unpredictability poses unique challenges to municipalities. The following section will describe the provincial interferences in municipal matters and the associated consequences faced by municipalities. 


\section{PROVINCIALLY IMPOSED CHANGES TO MUNICIPALITIES}

This section will elaborate upon the ways in which municipalities have been treated as subordinate to other levels of government. Specifically, this section will address the effects of provincial downloading, unpredictable transfers, and the amalgamations in Winnipeg, Montreal, Ottawa, and Toronto. The concluding paragraph will focus on the recent electoral redistricting in Toronto, and how it intersects with the aforementioned themes. It is important to note that there is also extensive literature (though not the focus of the section below) about municipal autonomy that reflects a long-standing historical debate in Canada about urban sovereignty (Keil and Young, 2003, pg. 87).

\section{A. Downloading}

During the late 1990s, municipalities experienced greater downloading and pressure for the delivery and financing of vital services. These responsibilities ranged from increased pressure to develop infrastructure such as roads, to the expansion of social services and policing services. These changes did not affect all municipalities uniformly as the size of the city dictated its ability to adapt. This downloading created an even more complex dynamic between provinces and municipalities, as will be explored below.

It is important to note that while there has been significant downloading of responsibilities onto municipalities, provinces have, in many instances, intervened to help manage municipal services. However, this intervention is not necessarily welcome in municipalities if these actions are undertaken unilaterally. In the past, provinces have created agencies, boards, and commissions to organize local powers, reflecting a mentality that some local concerns should be managed provincially (Lazar and Seal, 2005, p.40). For example, the 
province has intervened in the creation of transit and housing authorities, school boards and police commissions.

While most responsibilities of local government are defined in legislation, provinces have regularly amended that legislation (Lazar and Seal, 2005, p.34). In 1990, the provincial government in Quebec made a unilateral change to increase municipal responsibilities in the areas of public transit and policing. The Nova Scotia government also downloaded responsibility of roads and policing to the Halifax Regional Municipality. In 1997, the Ontario government increased municipal social service responsibilities, putting greater pressure on the budget of Toronto, in particular. Since 1995, provincial and federal governments have also placed the burden on municipalities to solve complex issues such as household food insecurity while reducing funding (Collins et al., 2014, p. 138). At this time, Ontario municipalities were also mandated to fully cover the cost of policing services. While large and medium sized municipalities were able to absorb these costs, smaller municipalities found this put much strain on their budget and further limited their resources (Siegel, 2006, p.185). After the Harris government's reforms in 1997-1998, the province was no longer responsible for providing capital and operating grants for municipal transit. Instead, the existing commitments for capital grants were fulfilled but no further grants were provided for operation or future capital costs (Siegel, 2006, p.187). These examples are illustrative of many changes in the late 1990s that led to greater downloading and pressure on municipalities for the delivery and financing of vital services. A prominent issue has been shifting transfers, which is elaborated upon below. 


\section{B. Shifting Transfers}

To contextualize the discussion of the Common Sense Revolution in the late 1990s, it is important to understand that motivations for cost reduction emerged much earlier and fluctuated over time. These changes in funding often occur in parallel with changes in municipal structures. Local partnerships have changed with time, beginning with city-county separation, followed by regional governance models (Seigel, 2006 p. 182; Ontario, Committee on taxation 1967; Spicer, 2013, p.4). The 1849 Baldwin Act separated urban and rural areas, lasting until the 1970s, when provinces substantially shifted to the regional growth model, during which time a cost-reduction mandate was pursued to accommodate the new system of regional government (Siegel, 2006, p. 184; Spicer, 2013, p.4). These changes put pressure on municipalities. Cities complain that these fluctuations in funding occur in an ad hoc fashion making it difficult for them to budget under these unpredictable fluctuations (FCM, 2013, p.24; Siegel, 2006, p.183).

In terms of unilateral financial changes, municipalities can be highly vulnerable to changes in intergovernmental transfers which they depend on to finance their programs, especially after experiencing downloading (Lazar and Seal, 2005, p.36). However, provinces have often reduced these transfers or attached conditions in order offset pressures from reductions in their federal transfers. Examples of shifting transfers are described below with a focus on the important example of radical financial restructuring which occurred during the Common Sense Revolution under the Mike Harris government in 1997-1998 (Siegel, 2006 p. $183)$.

Under Harris, Ontario wanted to increase transfer payments to boards of education (which are technically part of municipal government) to gain greater control over these bodies, 
while at the same time removing property tax funds from the boards and allowing municipalities to "occupy the property tax room vacated by boards of education" ( Siegel, 2006 p. 183; Sancton, 2000, p.148). Under the new structure, municipalities would have fewer provincial transfers due to the increase in revenue from property taxes (Siegel, 2006, p.183). This restructuring was similar to unilateral funding changes that have taken place in Alberta and Quebec (Lapointe 1980; Siegel, 2006, p.183). The goal was that the province could reduce transfer payments to municipalities because the cities would increase their reliance on the property tax, leaving room for the province to increase transfer payments to the boards of education ( Siegel, 2006, p.183). In reality, the school boards still ended up receiving a share of their funding from the property taxes, while municipalities underwent the unwelcome change of increasing their reliance on property taxes and user fees instead of provincial transfers (Siegel, 2006, p.183).

Recent events in Toronto also help illustrate the precarious nature of provincial support for municipalities. In 2017, the City of Toronto proposed a new toll on the Gardiner Expressway as a means of securing additional city funding. While Liberal premier Kathleen Wynne originally supported Toronto's plan, she rescinded her support to avoid placing herself at a political disadvantage in the 2018 election (Crawley 2016; Crawley 2017; Benzie 2017; Shum 2017). Considering that the tolls would disproportionately affect commuters from the suburbs - a large demographic whose support is significant for winning government - the province refused to approve the plan. Without the province's approval, the City of Toronto could not impose the toll and was blindsided by this unilateral and abrupt change in the province's support (Crawley 2016; Crawley 2017; Benzie 2017; Shum 2017). However, to compensate for the withdrawal of their 
support, the province extended the cooperative gesture of doubling the gas tax revenue allocated to the city (Crawley 2017; D'Amore and Fox 2017). This change would provide Toronto with additional funding of $\$ 170$ million per year, though on the province's, rather than the City's terms. In addition to these financial concerns, provinces have also created difficulties for municipalities in the form of institutional restructuring, such as amalgamations.

\section{Amalgamations}

A prominent trend in provincial interference is amalgamation and annexation for the purpose of cost-savings (Lazar and Seal, 2005, p.31). While there are some limited examples of mergers supported by popular referendum - British Colombia's Abbotsford and Matsqui — most cases, such as Halifax, Nova Scotia, Miramichi, New Brunswick, and Toronto, Ontario, have occurred without public consultation and against public will (Lazar and Seal, 2005, p.31). While the argument most commonly made in support of the mergers was to reduce costs, most cases involve increased bureaucracy and transition expenses that surpass savings (Lazar and Seal, 2005, p.31).

\section{Restructuring in Winnipeg}

In 1972, the NDP provincial government amalgamated twelve municipalities in the greater Winnipeg area into a unicity (Sancton, 2001, p.544). Mounting pressures in the 1960s prompted this change. These pressures arose under the Metropolitan form of government due to frequent tensions between the administrators of the Metropolitan Corporation of Greater Winnipeg $^{2}$ and the Mayor and Council of the City of Winnipeg (Axworthy, 1978, p. 4). Under the City of Winnipeg Act of 1972, local services were streamlined under the new single municipal administration (Nader, 1976, p.293). In contrast to the rationale behind the

2 The Corporation of Greater Winnipeg has an analogous structure and functionality to an American urban county (Sancton, 2001, p.545). 
amalgamations in Ontario, the Manitoba NDP's objectives did not relate to cost-savings. Instead, the provincial government argued that the merger would promote economic expansion and improve service delivery (Sancton, 2001, p.545). While the amalgamation achieved some of the stated objectives, including equalizing the property tax rate across the new unicity, a provincial Committee of Review appointed in 1975 deemed it a failure due to problems in the unicity's political structure (McAllister, 2014, p.104; Wichern, 1986, p.1). The new city structure disproportionately favoured suburban councillors and led to greater suburban development at the expense of inner-city development (Sancton, 1995, p.24; Axworthy, 1978, p. 14).

Another issue that arose was a lack of public consultation which eventually led to significant community backlash. For example, a rural area called Headingley seceded from the unicity in 1992 after a local referendum held by Conservative provincial government showed that $86.7 \%$ of Winnipeg locals supported the secession (Sanction, 2001, p.544). The amalgamation also caused shifts in public representation; suburban interests dominated the new municipal council since, under the new amalgamated city, most of the population lived in suburban neighbourhoods (Sancton, 2001, p. 545).

\section{E. Restructuring in Montreal}

In the case of Headingley, the amalgamation occurred due to rural-urban divides. Montreal also saw a series of demergers, but they occurred largely due to language considerations (Miljan and Spicer, 2015, p.9). These demergers occurred following provinciallyimposed mergers of several municipalities, just previously. 
In December 2000, the Parti Quebecois ${ }^{3}$ provincial government consolidated 213 municipalities into 43. This included the consolidation of 28 municipalities on the Island of Montreal into a megacity (Miljan and Spicer, 2015, p.13; Smith, 2007, p. 10; Spicer 2014). The new Montreal Metropolitan Community covered the entire urban area as well as an overarching tier of government (Miljan and Spicer, 2015, p.13; Sancton, 2011). The suburban municipalities themselves were against this merger and held public consultations and took the matter to court to prevent the amalgamation (Miljan and Spicer, 2015, p.14; Vaillancourt and Meloche, 2013). English-speaking cities also resisted being merged into cities where French speakers would become the majority (Lazar and Seal, 2005, p.32; Boudreau et al., 2006 p.16).

A series of referendums were held in 2004 by the newly elected Liberal Party in Quebec, allowing municipalities to de-amalgamate (Sancton 2006; Miljan and Spicer, 2015, p.14). On January 1, 200631 municipalities (15 on the Island of Montreal) de-amalgamated, leading to the existence of four levels of government with separate mayors including the Agglomeration (an upper-tier structure responsible for delivering higher-order services across the Island of Montreal), the City of Montreal, the boroughs, and the Montreal Metropolitan Community (Miljan and Spicer, 2015, p.14; Sancton, 2011).

\section{F. Restructuring in Ottawa}

The rationale behind the province of Ontario's restructuring in Ottawa held a similar narrative to that of Winnipeg, including promises of enhanced municipal services and administrative simplification (Graham, Maslove, and Phillips, 2001, p.252; Rosenfeld and Reese, 2003, p. 59). However, the province's plan to amalgamate Ottawa into a single-tier municipality

\footnotetext{
${ }^{3}$ Readers are advised to consider the detailed story of Westmount in Peter F.Trent, The Merger Delusion: How Swallowing Its Suburbs Made an Even Bigger Mess of Montreal (Montreal and Kingston: McGillQueen's University Press, 2012).
} 
also projected outcomes such as financial savings, fewer local politicians, and greater accountability (Graham, Maslove, and Phillips, 2001, p. 252; Rosenfeld and Reese, 2003, p. 59).

One of the province's earlier interferences in Ottawa occurred in 1969 with the creation of Regional Municipality of Ottawa-Carleton (RMOC), an upper-tier regional municipality containing 16 lower tier municipalities: the Cities of Ottawa and Vanier; the Villages of Rockliffe, Richmond and Stittsville; and the Townships of Torbolton, Fitzroy, Huntley, March, Goulbourn, Nepean, Osgoode, Marlborough, North Goer, Gloucester and Cumberland. (Graham, Maslove, and Phillips, 2001, p.254). The provincial agenda for urban restricting included establishing two-tier regional governments that would amalgamate rural municipalities, city centres, and suburbs across Ontario. These changes were motivated by the Ontario Committee on Taxation's 1967 report which suggested that provincial governments should use a two-tier local government format to capture different economies of scale for urban service delivery.

In terms of political unity, the amalgamation failed to create a sense of regional identity since the RMOC territory was largely rural but the majority of the population was found in the City of Ottawa, causing the city to feel like it was funding suburban activity at the expense of inner-city development (Graham, Maslove, and Phillips, 2001, p.255). Meanwhile, the suburbs felt threatened that their identities would be suppressed in the unification. This concern was realized in 1973 when the province forced the creation of 11 lower-tier municipalities from the previous 16.

Public unrest with the two-tier system peaked in the 1990 s, causing the province to evaluate the Ottawa Board of Trade's recommendation (in place since the 1980s) to adopt a single-tier government (Graham, Maslove, and Phillips, 2001, p.259). The Board argued that 
there were delays and inefficiencies created from attempting to coordinate with two tiers of government. The council for the City of Ottawa, which was the biggest lower-tier municipality, and the majority of regional councillors supported the single tier proposal. Meanwhile, suburban councils were opposed out of fear they would continue to lose their local identities, pay higher taxes to absorb the City of Ottawa's debt (Rosenfeld and Reese, 2003, p.65), and face a reduction of services tailored to their demographic needs (Graham, Maslove, and Phillips, 2001, p.259).

Despite the best efforts of suburban protestors, amalgamation discussions resumed in 1999 when the Conservatives regained power (Graham, Maslove, and Phillips, 2001, p.260). The Minister of Municipal Affairs designated the restructuring efforts to an appointed group of “special advisors" (Graham, Maslove, and Phillips, 2001, p.260; Spicer, 2016, p.137). The advisor for Ottawa held relatively few public meetings and proposed the one tier model to the Conservative government after consulting with the municipal leaders (Graham, Maslove, and Phillips, 2001, p.260). The provincial government acted upon this recommendation despite suburban protests and reformed Ottawa into a single-tier municipality on January 1st, 2001 (Graham, Maslove, and Phillips, 2001, p.260; Spicer, 2016, p.138). In contrast to the goals stated at the onset of the amalgamation project, the Ottawa Transition Board's draft of the 2001 city budget failed to show tax savings for residents or significant improvements in service delivery (Rosenfeld and Reese, 2003, p.59).

\section{G. Restructuring in Toronto}

In 1953, the province created Metropolitan Toronto - the first Ontario city to adopt a two-tier government structure - due to the spike in suburban population growth and the lack of a suburban tax base to finance services and infrastructure to support these growing populations 
( Spicer, 2014, p. 246; Boudreau et al., 2006, p.31-32; Côté and Fenn, 2014, p.8; Slack and Bird, 2013, p.8). Thus, the two-tier structure was adopted to relieve financial pressure in the suburbs by sharing costs with the City of Toronto, which had a strong financial base (Côté and Fenn, 2014, p.8; Slack and Bird, 2013, p.8). The costs for the new amalgamated region were divided on the basis of the property tax base, which placed disproportionate pressure on the City of Toronto: it paid $62 \%$ of the total costs of Metro in 1954 and gradually took on greater service delivery responsibilities (Slack and Bird, 2013, p.8). Further provincial interference occurred in 1967 when the number of cities in Metro was reduced to 6 from the previous $13^{4}$ (Slack and Bird, 2013, p. 17).

The province once again interfered in Toronto municipal matters in 1998 (Boudreau et al., 2007, p.33). Under the Conservative leadership of Mike Harris, several cities including Toronto, Scarborough, North York, Etobicoke, York — and one borough — East York were amalgamated into a megacity (instead of following an expert panel's advice to search for a regional solution that would have integrated the rest of the GTA) (Boudreau et al., 2007, p.33). The rationale for the decision echoed the rhetoric used for the parallel merger in Ottawa: cost savings, elimination of waste, and political simplification (Graham, Maslove, and Phillips, 2001, p. 258). The financial projections at the time predicted $\$ 635$ million in savings after the amalgamation, $\$ 300$ million in savings annually, and no more than $\$ 220$ million in transition costs (as claimed by KPMG consulting firm). The reality after the amalgamation was that the

\footnotetext{
4 "Forest Hill and Swansea were amalgamated with Toronto; New Toronto, Mimico, and Long Branch with Etobicoke; Weston with York; and Leaside with East York. North York and Scarborough (with Etobicoke, York, and East York) became the five boroughs which, together with the City of Toronto, constituted the Metro region" (Slack and Bird, 2013, pg. 17).
} 
city saved only $\$ 135$ million, and that transition costs exceeded the projection by $\$ 55$ million (Schwartz, 2009, p.484).

In the longer term, the increased complexity of local governance and provincial downloading under amalgamated structures increased costs (Schwartz, 2009, p.484). Bish (2001) undertakes an expansive literature review to determine that the least expensive local governments are "found in polycentric systems of small and medium-sized municipalities that also cooperate in providing those services that offer true economies of scale" and there is no convincing relationship to prove municipal unification increases economic growth (p.20). Such a finding is inconsistent with the provincial government's stated goal of reducing costs.

In terms of public opinion, the old core of the City of Toronto strongly opposed unification, and this sentiment was echoed by others in a non-binding plebiscite where $70 \%$ of respondents voted against the merger (Boudreau et al, 2007, p.33). As in the cases of Winnipeg and Ottawa, public opinion did not stop the province from proceeding with the merger (Boudreau, 2000; Boudreau et al, 2007, p.33; Graham, Maslove, and Phillips, 2001, p. 258). This paper will return to the consider implications of public opinion below, but suffice it to say at this point that public opinion in Toronto was, by all accounts, largely opposed to amalgamation.

\section{H. Recent Restructuring Events Toronto}

In 2018, Ontario Premier Doug Ford passed the Better Local Government Act (Bill 5) to reduce the size of Toronto City Council from a planned 47 to 25 wards, aligning municipal wards with provincial ridings (Keenan 2018). Similar to the rationale behind previous provincial restructurings, Ford claimed there would be financial benefits and would make service delivery more efficient. However, he is widely accused of undertaking this change for political benefit 
(Oved 2018; Keenan 2018). The pre-election 44 ward model disproportionately favoured suburban voters, in that there were fewer electors per ward/councilor in the outlying areas of the city than there are downtown. The proposed 47 ward model was designed to help equalize representation by adding downtown seats (Oved 2018). The new 25-ward model not only realigns the ward distribution to once again provide a suburban advantage, but also reduces representation overall, as there are fewer councillors to represent Torontonians (Keenan 2018; Oved 2018).

Further criticisms include that the redistricting decision occurred unexpectedly, less than 100 days before the municipal election, creating confusing in the democratic process (Pagliaro 2018; Rieti 2018; Keenan 2018). The City of Toronto, and other interested individuals with standing, argued in front of a judge that intervening during an election represented an infringement of the voting rights guaranteed in the Charter of Rights and Freedoms and that the province has an obligation to consult with the City as per the City of Toronto Act and a bilateral cooperation agreement (Gray 2018). However, provincial lawyers argued that there are no legally binding enforcement mechanisms for consultation in either agreement (Gray 2018). Regardless of the legal ruling, lawyer Howard Goldblatt explains that the decision to redistrict three quarters of the way during the election meant that most candidates wasted their campaign money until that point and that it would be exceedingly difficult for them to raise additional funds (Gray 2018).

Similar to the rationale provided in previous provincial realignments, Ford argued that the redistricting would help save taxpayer dollars: $\$ 25$ million over the following four years. However, Toronto's staff estimate that the shift would cost $\$ 2.5$ million alone in additional 
election costs (Pelley 2018). Further, some argue that the cost savings over four years due to this initiative will be trivial (Levine 2018). The savings represent only one-twentieth of one percent of Toronto's' annual operating budget over four years (Filipowicz 2018). Indeed, this situation is similar to Harris' reforms in the 1990s in that the official rationale behind these changes were financial (Keenan 2018: Trosow 2018) but other motivations are suspected by many observers. Harris' reforms also reduced the number elected officials and were supposed to make government more efficient and thus to save taxpayer money (Filipowicz 2018).

An array of actors lined up against the provincially imposed redistricting. The Toronto District School Board protested against the changes, raising concerns about lack of public and stakeholder consultation (Pelley 2018). The City of Toronto complained that its plan to increase the districts from 44 to 47 required almost four years of review and consultation (Gray 2018), while many others pointed out that the redistricting decision occurred with no prior consultation from the public or the City (Pelley 2018). Toronto law firm Goldblatt Partrtners also spoke out against the intervention, arguing that the decision to redistrict in the middle of the election would restrict political expression and would negatively affect marginalized communities that are underrepresented in local government (Pelley 2018).

Some of the arguments against the change focused on the idea of "effective representation" which is an important democratic concept stipulating that different geographically-based interests should be given equal weight (Lorinc 2018). The Conservative government counter-argued that the redistricting actually helped to increase voter parity, given that the new wards were based upon boundaries accepted by the other orders of government. Parity aside, the fact that new wards were to have 110,000 residents, on average, which is nearly 
double the average value under the 47-ward system, bodes poorly for effective representation (Lorinc 2018; Gray 2018).

Similar complaints and legal challenges arose during Harris' amalgamation in 1997, but the court declared there was no constitutional obligation for the province to consult or negotiate with municipalities given that the province created the municipalities and therefore has the right to modify or disunite them (Pelley 2018). Again, Section 92(8) of the Constitution provides provinces with jurisdiction over cities, allowing Ontario to create the Municipal Act, Municipal Elections Act, and City of Toronto Act which regulate local governance, elections, and ward distribution respectively. Until recently, some authors have claimed that provincial-municipal relations have been improving, such as through the Municipal Act of 2001 and 2006 City of Toronto Act which allowed Toronto to have greater autonomy (Kastarov 2018; Lazard and Seal. 2005, p.28). However, the recent unilateral redistricting that occurred without consultation either with the City or public is clearly a significant setback in Ontario-Toronto relations (Trosow 2018; Lazar and Seal, 2005, p.28). The paper will now turn to explore some of the deeper problems related to the province's disregard for public opinion, beginning with a discussion about the value of government responsiveness and how it relates to fundamental democratic principles. 


\section{PUBLIC OPINION}

Having covered the history of municipal intergovernmental relations, as well as an account of past provincial interventions in local politics, this paper turns now to a discussion of the importance of considering public opinion towards the province's 2018 unilateral redistricting in Toronto. Government responsiveness to public opinion helps enhance citizens' trust in the democratic process, but responsiveness can only occur after opinion has been measured. Public opinion is also important to consider in that may predict the likelihood of urban activism, which can help shape policy agendas. The section will begin by briefly summarizing the academic debate about the extent of government responsiveness to public opinion. Next, background on public consultation will be provided, followed by a discussion of urban activism, and ending with a critical summary of how government responsiveness in Canada is affected by the country's federal structure. It is also important to note that responding to public opinion is only one way that governments make decisions. Some decisions are based on campaign promises, and there are also situations where it is inappropriate for governments to primarily rely on public opinion. Keeping in mind that responsiveness is only one measure of government legitimacy, the following section discusses the importance of government responsiveness to public opinion more narrowly.

\section{A. Why Should the Government Be Responsive?}

First, "responsiveness" refers to governments that accommodate changing citizens views by adjusting policy according to those preferences (Tausanovitch and Warshaw, 2014, pg.3). Responsiveness is the bedrock of a representative democracy; citizens should be able to influence the government's policy decision given that it was elected to represent the people (Tausanovitch and Warshaw, 2014, pg.3; Achen 1978). Scholars of democratic theory have 
emphasized the importance of responsive rule, arguing that there should be correspondence between citizen opinions and government policy choices (Soroka and Wlezien, 2010, pg.1). This type of responsiveness is crucial for maintaining public trust and government accountability (Soroka and Wlezien, 2010, pg. 2). Other scholars go further and explain that the current democratic deficit - characterized by low voter turnout and low public trust of officials - is due to dissatisfaction with the level of government responsiveness (Dalton et al., 2001, pg.141). If governments are not responsive to public opinion, it could further exacerbate the democratic deficit and cause policies to emerge that are inconsistent with citizens' needs and desires. Some scholars argue that democratic structures that are more deliberative (and therefore engage citizens more directly) may reduce democratic deficits (Nabatchi, 2010, pg.2). American political scientist V.O. Key Jr once asserted that "unless mass views have some place in the shaping of policy, all the talk about democracy is nonsense. As [Harold] Lasswell has said, the open interplay of opinion and policy is the distinguishing mark of popular rule" (Shapiro, 2011, pg. 982; Key 1961, p. 7) and this goes beyond simply electing officials (Shapiro, 2011, pg. 982).

\section{B. Is the Government Responsive to Public Opinion?}

First, it is important to establish why governments ought to engage with and respond to the public. Some argue that public engagement helps the government collect dispersed information about people's policy preferences in order to make more effective policies (Harrison et al, 2012, p.27). Increased input from citizens not only helps enhance understanding of citizens' needs, but also allows the government to draw on a variety of expertise and knowledge (Harrison et al, 2012, p. 28). In addition, citizens in a democracy expect that governments will be responsive to their needs and failure to engage with citizens may lead to public mistrust and 
democratic deficits (Abelson et al., 2004, pg. 2). Furthermore, public engagement improves accountability relationships, increases transparency, and reaffirms the governments' role as the "guardian of the public interest" (Abelson et al., 2004, pg. 2). As such, it is important to investigate if government is sufficiently engaging with the public, while also keeping in mind that engagement is not necessarily neutral. The advent of mass media and the increasing sophistication of polling and campaign technologies has made it easier for political elites to access, distort, and potentially manipulate public opinion (Manza and Cook, 2002, pg. 657).

In order to measure government responsiveness, it is first important to understand that there are a variety of channels through which individuals can express policy preferences. Historically, there have been many ways for citizens to express their views: salons, riots, coffeehouses, strikes, letter-writing campaigns, petitions, activism and social movements, polls, and of course, elections (Manza and Cook, 2010, p.632). Some scholars argue that today public opinion is largely expressed through forms of "active" opinion in which people convey views by participation in organizations and social movements. On the other hand, "latent" opinion which represents people's underlying policy preferences; and "perceived" opinion which is presented in media as an agglomeration of public sentiments, though it may not accurately reflect them (Manza and Cook, 2002, p.632).

Some scholars use the thermostat metaphor to describe public consultations: "when the 'policy temperature' is too low, a responsive public calls for more policy, and when the 'policy temperature' is too high, a responsive public calls for less" (Soroka and Wlezien, 2010, p.3). Consistent with this model, Petry and Mendelsohn describe how governments are more likely to be responsive when there is greater public consensus about the direction of the proposed policy 
change (Soroka and Wlezien, 2010, p.4; Petry 1999; Petry and Mendelsohn 2004). In general, there are three primary ways that governments engage with these opinions: via election results, public consultations, and elected officials (Petry, 2005, p.22). In terms of government responsiveness to these opinions, some scholars argue that politicians may try to close the distance between their stated policy positions and the public positions in order to ensure that they can be elected or re-elected (Manza and Cook, 2002, p.633). Not only do politicians respond to citizens for electoral purposes, but they may also do so to help justify their own policy preferences by making it appear that their policies address public concerns (Manza and Cook, 2002, p.657).

Scholars have also argued that the public themselves are increasingly demanding that government be responsive to them, and that government respond meaningfully to citizens' concerns (Erikson et al. 1993: Stimson et al., 1995; Page 2002; Burstein 1998). After the failure of the Meech Lake Accord, Canadians wanted greater public consultation in an effort to increase transparency (Soroka and Wlezien, 2010, pg.1; Watts and Brown 1990; Cairns 1991). Accordingly, governments have pursued Royal Commissions and Citizens' Assemblies to engage with Canadians (Soroka and Wlezien, 2010, pg.1; Howe et al. 2005; Seidle 2007). Government responsiveness has increasingly become a norm in Canadian politics.

Some political scientists say that there may be an overestimation of government responsiveness given that most of the data relates to high-priority areas and the government is more likely to respond to public opinion on popular issues (Page 2002; Page and Shapiro 1983; Burstein 2003, 2006). Others argue that governments only respond to citizens' 'global' (i.e general or broad) preferences about matters, such as overall attitudes towards spending on 
different important policy areas (Burstien, 2010, p.64; Wlezien 1995,2004; Soroka and Lim 2003; Soroka and Wlezien 2005; Brooks and Manza 2007; Erikson et al. 2002; Soroka and Wlezien, 2010, pg. 5; Monroe 1979; Page and Shapiro 1992). In Canada, governments are more likely to be responsive to broader public wishes such as the general level of spending rather than the specific policies on which that money is spent (Soroka and Wlezien, 2010, pg. 5). This reaction from the government in part arises due to the fact that the Canadian public tends to focus on global issues (Soroka and Wlezien, 2010, pg. 7). Another area of concern is that it is impossible to evaluate government responsiveness for some policies because voters are either uninformed or uninterested in certain topics. As such, there is no public opinion data available for evaluation (Burstien, 2010, p.65; Althaus 2003; Zaller 1992; Petry 1999; Petry and Mendelsohn 2004). Despite the apparent limitations with measuring and responding to public opinion, it is nevertheless important for governments to be responsive. For this reason, it is important to measure public opinion on significant issues such as redistricting. Exploring the background of public consultation in Canada will help elaborate upon the purpose and value of public consultation.

\section{Background on Public Consultation}

Since the late 1960s, public consultation in municipal policy development has been a growing trend in Canada, in an attempt to sustain public trust and improve decision-making (Beckie et al., 2013, p.17; Masuda et al., 2008, p. 360; Petry and Birch, 2012, p.16; Healey, 2003; Innes, 1995; Calder \& Beckie, 2013; Cooper \& Vargas, 2004; Forrester, 2009; Innes \& Booher, 2004). Public consultation can help ensure policy reflects diverse view-points, improve government productivity, and tailor service delivery (Beckie et al., 2013, p.17; Healey, 2012, p. 
20; Pearce \& Littlejohn, 1997, p. 79). It also helps legitimize policy decisions by creating more responsive policies (Petry and Birch, 2012, p.17; Schrefler 2010). However citizen engagement in the initial development of a policy is individually insufficient to make it legitimate. There are other crucial variables at play including how the policy is designed, operationalized, and evaluated that should involve respect for regulatory procedures and the ability to justify the use of particular policy instruments (Petry and Birch, 2012, p.17; Schrefler 2010).

In general, public consultation is an important democratic tool to help voters to hold leaders accountable (Jacobs and Shapiro, 2005, pg. 1). This process is often time and resource intensive which has unfortunately caused some governments to pursue short-cuts that led to superficial consultation (Beckie et al., 2013, p.17; Rydin \& Pennington, 2000, p. 161). Insufficient public consultation can arise due to a lack of sincere government effort or due to strong internal influences exerted by high-level officials or special interest groups (Beckie et al., 2013; Rydin \& Pennington, 2000; McCann, 2001). Unfortunately, public opinion data show that most Canadians mistrust politicians (Marland et al., 2011, p. 19; Anderson and Goodyear-Grant 2006; Soroka and Wlezien, 2010, pg.1). Public consultation is an important tool for combatting this cynicism. For these reasons, it is important to consider whether the federal system in Canada affects government responsiveness.

\section{How does Federalism Impact Government Responsiveness?}

In a setting such as Canada, where power is divided between multiple orders of government, distinctions between the roles of government and clarity about policy decisions may be obscured, negatively affecting government responsiveness, accountability, and transparency (Simeon and Cameron 2002; Downs 1999; Cutler, 2004, p.19; Soroka and Wlezien, 2010, pg. 8). 
Culter (2004) warns that this confusion may have a negative impact upon how policy agendas are developed, decrease the level of government innovation, and discourage people from voting (pg. 21). The constitutionally entrenched levels of government, in particular, frequently share responsibilities because they can both justify a claim to jurisdiction. There is also overlapping policy influence through fiscal transfers that may constrain or guide the behaviour of the government responsible for policy implementation (Soroka and Wlezien, 2010, pg. 9).

This arrangement makes it difficult for the public to keep track of the responsibilities of each level of each government (Soroka and Wlezien, 2010, pg. 10). For example, roughly $60 \%$ of welfare spending between 1988-2005 came from the federal government, while the remainder was split between municipal and provincial governments (Soroka and Wlezien, 2010, pg. 10). Of the $40 \%$ spent by municipal and provincial governments, a portion of this funding came in the form of conditional grants from the federal government. For this reason, it may be difficult for the public to clearly assign responsibility for policy decisions to a particular branch of government. This trend is also visible in the United States where city dwellers punish and reward mayors for policy effects both within and outside of their control (Arnold and Carnes, 2012, p. 951). However, there are also scholars who argue that federalism enhances representation because there are more opportunities for citizens to broadly express policy preferences through different levels of government (Soroka and Wlezien, 2010, pg. 10; Trudeau 1968; Downs 1999). Having established a robust background on the importance of public opinion and how different levels of government engage with citizens, this paper now turns to a discussion of its central analysis. 


\section{RESEARCH QUESTIONS}

The purpose of this major research paper is to examine public opinion towards the exercise of provincial powers over municipalities, and to identify the correlates of support for such powers, using the recent redistricting in Toronto and survey data from the Toronto 2018 municipal election as a case study. The piece will address these questions by investigating Torontonians' attitudes on two core questions: support for provincial control over municipal matters and support for ward redistricting in 2018. It is important to first investigate broad support for provincial intervention before narrowing in on the specific instance of redistricting. Formally then,

1) Do Torontonians think that the government of Ontario should have the power to make changes to Toronto's government?

2) Do Torontonians think it a good thing that Toronto City Council has been reduced in size?

More specifically, the paper will test a series of hypotheses in order to identify how different individual-level characteristics affect people's attitudes towards the two central questions. For example, this paper will look at (H1) partisan attitudes; (H2) ideological attitudes; (H3) perceptions of responsiveness from different levels of government; (H4) perceptions of importance of the levels of government; and (H5) issue importance of ward boundaries. These analyses will include controls for respondents' ward, gender, education, and age.

Formally then, this paper's expectations are as follows:

\section{Hypothesis 1}

Conservatives are more likely to support provincial powers and redistricting in Toronto than are opposition partisans 
It is also important to note that partisan attitudes will be divided into three groups: Conservatives, opposition partisans, and non-partisans. Opposition partisans includes the other (left-leaning) groups that are likely to oppose the Conservative's change: NDP, Liberal, Green, and other. It is reasonable to group the opposition together since they are likely to have negative attitudes towards the Conservative government's intervention and also because they have some ideological similarities.

Conservatives may support redistricting on two grounds. First, the decision was made by a Conservative leader and Conservative voters may have loyalty to these leaders' decisions. There are two narratives present in the literature: voters have independently formulated positions on certain policy issues irrespective of partisan bias or the "partisan contamination" hypothesis which suggests that voters' positions on issues are influenced by their partisanship (Evans and Anderson, 2007, pg. 18). Evans and Anderson (2007) find support for the latter hypothesis: people's perceptions of policy issues are strongly influenced by their partisan attitudes. Based on this research, it is reasonable to suggest that Conservatives may support certain policies based on their partisan loyalties. For example, while Conservatives are typically in favour of smaller government, they may support invasive, "big government" action such as the provincial government interfering with municipal government if this policy is enacted by a Conservative leader.

Second, given that the new ward distribution favours suburbs that are more likely to vote Conservative $^{5}$ (Oved 2018), Conservative respondents may support the redistricting as an opportunity to increase conservative voices on council. Furthermore, Conservative voters tend to 5 See Toronto Case Study Section for further details 
dislike big government as compared to the opposition partisans. The redistricting not only represents a shift to greater conservative voices, but also decreases the number of politicians which is something that Conservatives have supported in the past, as with the reforms under the Harris government. For these same reasons, opposition voters may oppose the redistricting decision.

It is also useful to analyze whether voters' partisan attitudes also affect their opinion of more provincial control over municipalities. If, for the reasons stated above, Conservatives are supportive of provincially imposed redistricting in particular, they should also be very likely to also support provincial powers in general. Consistent with this logical structure, non-partisans are therefore unlikely to identify in the same ways as Conservatives and opposition partisans; instead, they are more likely to respond neutrally to each question.

\section{Hypothesis 2}

H2A) Right-leaning individuals are more likely to support provincial powers and redistricting

\section{in Toronto than will left-leaning individuals}

It is valuable to consider the effects of ideology, separate from partisanship, on attitudes towards the two central questions. Partisanship and ideology are usually correlated but do not always align exactly (Jou and Dalton 2017). However, some scholars argue that political values are significantly informed by social identification with a political party; in other words, people's partisan preferences shape their value positions (Goren, 2005, pg. 895). Partisanship strongly influences people's ideological positions and this positioning overpowers issue-based preferences; this phenomenon can be referred to as partisan contamination (Inglehart and Klingemann 1976; Jou and Dalton, 2017, pg. 14) and some scholars have found that voters may 
adopt the stance of their preferred parties by default (Brody \& Page 1972; Jou and Dalton, 2017, pg. 14). It is also important to note that there may not be ideological and partisan alignment among some voters if they are not politically knowledgable. In this case, they may find it easier to identify with parties than with abstract ideological terms (Brody \& Page 1972; Jou and Dalton, 2017, pg. 14). Given this information, I expect that the responses for Conservatives will align (though imperfectly) with the response of right-leaning individuals and the same trend for opposition partisans and left-leaning individuals. Due to the imperfect alignment between partisanship and ideology, it is important to consider them separately in the analysis. Ideology can also affect partisanship, and this effect may be stronger. The primary exception is that rightleaning individuals will be in favour of smaller government. In other words, they may support policies that reduce bureaucracy and the number of politicians. Therefore I expect that rightleaning individuals will be more likely to respond positively to questions 1 and 2 as compared to left-leaning individuals. In recognition that partisanship and ideology are not perfectly correlated with one another, both variables are included in the models below.

\section{Hypothesis 3}

H3A) Respondents who believe that municipal governments are responsive are likely to be opposed to provincial powers and redistricting in Toronto, as compared to those who do not feel municipalities are responsive

It is also relevant to compare how people's attitudes to the research questions are related to perceptions of the responsiveness of local government. It seems likely that the individuals who believe that municipal politicians are attentive to their needs will respond negatively to both central research questions. That is, respondents who are satisfied with the responsiveness of local 
government will be generally opposed to policies which would see the power of local governments decrease. Some scholars have demonstrated that public satisfaction with municipal services increases when municipalities respond to citizens' concerns in an organized, professional, timely, and courteous manner (Zhenming et al., 2010, pg. 233). As mentioned previously, municipal governments may be responsive to citizens such as in the case of Edmonton's sustainable urban food and agricultural strategy that was designed based on citizens' needs (Beckie et al, 2013, pg. 16).

Also relevant to this hypothesis is the fact that significantly fewer councillors were elected in 2018 than was the case before. As mentioned previously, the redistricting involves the reduction of the number of councillors which means that the number of constituents per councillor is greater under the current system than under the old arrangement. As such, the new system is likely to be less representative than its predecessor which means that people who value government responsiveness are likely to oppose this change.

\section{Hypothesis 4}

H4A) Respondents who believe that municipalities are an important level of government are likely opposed to provincial powers and provincially imposed redistricting in Toronto, as compared to those who do not think local government is important

People's perceptions of government responsiveness are also likely to align with their perceptions about the municipal government's level of importance. These attitudes are likely to be related, yet may not align perfectly because responsiveness is not the only criterion by which respondents may form perceptions about the importance of the municipal level of government. Following the logic from $\mathrm{H} 3$, it seems quite likely that individuals who believe that governments 
are responsive are also likely to believe that they are important. For this reason, the anticipated responses of individuals are similar between these two hypotheses. Individuals who believe that municipalities are important will likely support municipal autonomy and therefore not support provincial intervention. They will therefore probably respond negatively to both questions 1 and 2.

Hypothesis 5

H5A) People who believe that the issue of city council ward boundary changes is important are likely to be opposed to provincial powers and redistricting in Toronto

Those who believe that ward boundaries are important are more likely to be informed on this particular issue. One may reasonably expect that individuals who are informed on the issue are most likely to understand the negative implications of changing ward boundaries, and are therefore more likely to oppose redistricting. These individuals likely believe boundary changes are important because they recognize issues relating to gerrymandering (recall section 1), and how the division and number of wards can affect representation. Overall, those who believe ward changes are significant are likely to understand how reducing the size of the wards may negatively affect effective representation for the local population while simultaneously conferring a political advantage to the Conservatives during the provincial election. 


\section{DATA}

Data from the 2018 Canadian Municipal Election Study (CMES) are used to test the above hypotheses. The CMES posed a wide variety of questions to a total of 2,403 respondents; however, it is important to note that not all survey participants responded to every question. The data were collected during the pre- and post-election periods: pre-election from September 27th to October 22nd, and post-election from October 23rd to November 21st. Respondents were recruited via an initial phone call where their e-mail addresses were collected so that a survey link could be sent out electronically. The calls went out to individuals with both land lines and cell phone lines with Toronto area codes. Respondents were asked screening questions to ensure that they were eligible voters, including confirming Toronto residence and age. Finally, these sample results are weighted for age and gender to match the 2016 census and are therefore representative of and subsequently generalizable to the Toronto population.

\section{A. Key Variables}

In order to test each of the hypotheses, there are several key independent and dependent variables to consider. All variables have been coded to range from 0 to 1 to make the magnitude of coefficients comparable to one another. The following sections will categorize the variables as nominal, ordinal, or categorical variables while also outlining their relevance to the central research questions. The discussion will end with an overview of control variables and the types of analyses that will be used to test the hypotheses.

\section{B. Dependent Variables}

The dependent variables are related to the two central questions in this paper: attitudes towards redistricting and provincial control over municipalities. Both dependent variables are ordinal. 
Dependent Variable 1: The government of Ontario should have the power to unilaterally make changes to Toronto's municipal government

Dependent Variable 1 Responses: Strongly agree (1), Somewhat agree (2), Somewhat disagree (3), Strongly disagree (4), Don't know (9)

Dependent Variable 2: Is it a good thing that Toronto City Council has been Reduced?

Dependent Variable 2 Responses: Strongly agree (1), Somewhat agree (2), Somewhat disagree (3), Strongly disagree (4), Don't know (9)

\section{Independent Variables (Theoretical)}

The independent variables relate to the hypotheses H1-H5, some of which are ordinal and others which are nominal. Starting first with the H1 partisanship hypothesis, the independent variable is a nominal variable because it categorizes people as aligning with one of the political parties. It is important to note that the variables in $\mathrm{H} 1$ will be split up into two binary variables: Conservatives and opposition partisans, and the remainder will refer to non-partisans. The independent variable in $\mathrm{H} 2$ is ideology and is an ordinal variable because it asks individuals to rank their degree of ideological leaning. The independent variables in hypotheses $\mathrm{H} 3-\mathrm{H} 5-$ perception of municipal government responsiveness, perceptions of municipal government importance, and importance of ward boundaries - are all ordinal variables. For each of the hypotheses mentioned above, the question and response options are listed below:

H1 Question: In provincial politics, do you usually think of yourself as a?

H1 Responses: None, Progressive Conservative Party of Ontario, Green Party of Ontario, Ontario New Democratic Party, Other Provincial party, Don't know 
H2 Question: In politics people sometimes talk of left and right. Where would you place yourself on a scale from 0 to 10, where 0 means left and 10 means right?

H2 Responses: Responses range from 0 (far left) to 10 (far right) and don't know 99.

H3 Question: How much does the municipal government care about what you think?

H3 Responses: A lot (1), some (2), a little (3), None (4), Don't know (9)

H4 Question: Governments at all levels make decisions that have the potential to impact the lives of citizens. Please indicate how much impact the municipal government has upon your quality of life.

H4 Responses: A lot (1), some (2), not very much (3), none (4), don't know (9)

H5 Question: How important are each of the following issues to you in this election?(see item G

- ward boundaries)

H5 Responses: Please indicate each issue's importance on a 0-10 scale, where 0 means not at all important and 10 means extremely important

\section{Control Variables}

It is important to control for certain characteristics to help ensure that the regressions yield accurate predictions. If unaccounted for, the omitted control variables could influence the results and make it difficult to isolate the effect of the independent variable(s) on the dependent variable. For example, individuals who are educated may have values on the independent variables that differ systematically from those who are not, and it is therefore important to account for these differences when attempting to explain the dependent variables. The control 
variables included here are age ${ }^{6}$, gender ${ }^{7}$, education ${ }^{8}$, and living downtown (as opposed to the exterior of the city) $)^{9}$. Age and length of time lived in Toronto are interval variables; gender is a binary variable; and education is also a binary variable describing whether individuals have obtained a university education.

\section{The Type of Analysis}

The type of analysis appropriate for this study is an ordered logistic regression. This analysis was chosen because the outcome variables are ordinal. The central five hypothesis will be tested through a series of ordered logistic regression models, where explanatory variables include the independent and control variables mentioned above. This paper will include three regressions, denoted Unilateral, Council (1), Council (2) in Table 1. The first regression tests for respondents' support of provincial interventions in municipal matters generally. This analysis is followed up by a more specific investigation about attitudes towards the current instance of intervention: the recent reduction in the size of city council. The Council (2) regression is designed to specifically isolate the effects of people's opinions towards the 2018 redistricting, while controlling for their broader attitudes about provincial intervention. It is this final model which provides the most robust test of this paper's hypotheses. Finally, the most meaningful

\footnotetext{
${ }^{6}$ In what year were you born?

${ }^{7}$ Are you Male (1), Female (2), Other/Gender Non-Binary (3), Prefer Not to Say (9)?

${ }^{8}$ What is the highest level of education that you have completed? No schooling (1), Some elementary school (2), Completed elementary school (3), Some secondary/high school (4), Completed secondary/ high school (5), Some technical, community college (6), Completed technical, community college (7), Some university (8), Bachelor's degree (9), Master's Degree (10), Professional degree or doctorate (11), Prefer not to say/don't know (99)

${ }^{9}$ Suburbs: $1,2,3,7,6,8,518,17,16,15,22,23,25,24,20,21$

Inner City: 4, 9, 10, 11, 12, 13, 14, 19

Based on map: https://www.toronto.ca/wp-content/uploads/2018/08/95b0-2018_25Wards_11x17.pdf
} 
interpretation of the results from the ordered logistic regression found in Table 1 are the signs of the coefficients (indicating the direction of the level of support), rather than their magnitudes. 


\section{RESULTS}

Prior to conducting the multivariate results, it is worth describing the dependent variables. Figure 1 shows the share of respondents who support/oppose (1) provincial powers over municipalities and (2) the provincial imposed redistricting in Toronto. The right-hand pie chart ${ }^{10}$ represents respondents' attitudes towards the reduction of the size of city council.

\section{Figure 1: Distribution of Outcome Variables}

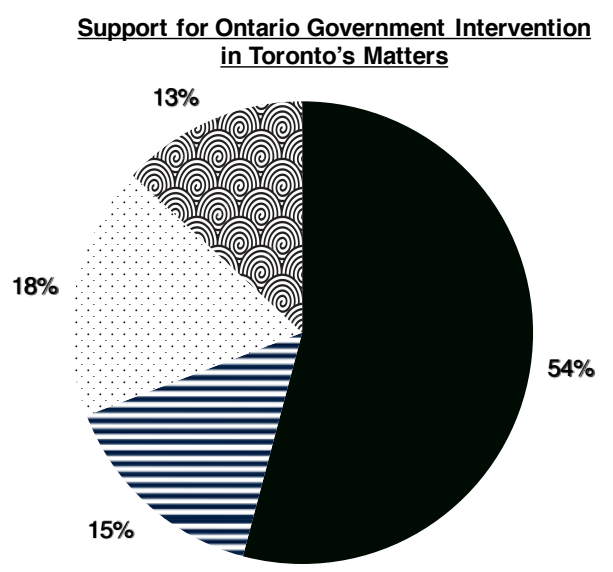
- Strongly Disagree $54 \%$ इSomewhat Disagree 15\% Somewhat Agree 18\% Strongly Agree 13\%
Support for Reduction of City Council Size

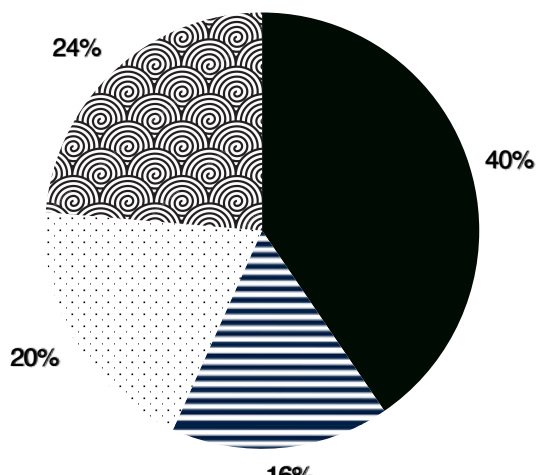

- Strongly Disagree $40 \%$ =Somewhat Disagree 16\% Somewhat Agree 20\% Strongly Agree 24\%

Most individuals (40\%) strongly disagree that the reduction was a good thing and $16 \%$ of individuals somewhat disagree that it was a good thing. Overall, $56 \%$ of the respondents have negative-leaning opinions about the reduction of city council, while the remaining $44 \%$ have positive-leaning opinion, $24 \%$ of which strongly agree that the reduction was a good thing. In terms of how this information aligns with the left-hand pie chart ${ }^{11}$, a larger proportion $(54 \%)$ of individuals strongly disagree that provincial intervention in municipal matters is a good thing. Overall, $69 \%$ of the respondents have negative-leaning opinions towards provincial

\footnotetext{
${ }^{10} \mathrm{~N}=2,216$ and people who responded with "don't know" were dropped.

$11 \mathrm{~N}=2,296$ and people who responded with "don't know" were dropped.
} 
interventions. Meanwhile, a mere $31 \%$ have positive-leaning opinions, where only $13 \%$ strongly agreed with provincial involvement. It is clear that people's attitudes on these two questions do not align perfectly, and hypotheses H1-H5 will be tested to help explain these differences.

Now that the distribution of the outcome variables has been determined, this paper turns to test the hypotheses above. To that end, Table 1 below shows the results of the aforementioned ordered logistic regression models. As noted previously, the columns represent the three different models and the rows show the relative significance of the independent variables under the regressions. 


\begin{tabular}{|c|c|c|c|}
\hline \multicolumn{4}{|l|}{ Intervention } \\
\hline $\begin{array}{l}\text { Independent } \\
\text { Variables }\end{array}$ & Unilateral & Council Size (1) & Council Size (2) \\
\hline Unilateral & - & - & $3.77(.26)^{* * *}$ \\
\hline Conservative & $1.47(0.18)^{* * *}$ & $1.61(0.20)^{* * *}$ & $0.94(0.26) * * *$ \\
\hline Nonpartisan & $0.32(0.24)$ & $0.48(0.23)^{* *}$ & $0.36(0.25)$ \\
\hline Ideology & $3.00(0.34)^{* * *}$ & $3.38(0.35)^{* * *}$ & $2.43(0.37)^{* * *}$ \\
\hline Care & $-0.34(0.23)$ & $-0.33(0.23)$ & $-0.22(0.25)$ \\
\hline Impact & $-0.92(0.31)^{* * *}$ & $-0.66(0.32)^{* *}$ & $-0.16(0.34)$ \\
\hline Important & $-1.63(0.20)^{* * *}$ & $-2.93(0.21)^{* * *}$ & $-2.72(0.22)^{* * *}$ \\
\hline Age & $-0.01(0.00)^{* * *}$ & $0.01(0.00)^{* *}$ & $0.02(0.00)^{* * *}$ \\
\hline Female & $0.52(0.13)^{* * *}$ & $0.2(0.13)$ & $-0.00(0.14)$ \\
\hline University Education & $-0.44(0.13)^{* * *}$ & $-0.33(0.13)^{* * *}$ & $-0.27(0.14)^{* *}$ \\
\hline Downtown & $-0.36(0.13)^{* * *}$ & $-0.52(0.13) * * *$ & $-0.47(0.14)^{* * *}$ \\
\hline /cut1 & $-0.73(0.42)$ & $-1.00(0.42)$ & $.26(.46)$ \\
\hline /cut 2 & $0.29(0.42)$ & $0.08(0.42)$ & $1.56(.46)$ \\
\hline /cut 3 & $1.71(0.42)$ & $1.63(0.43)$ & $3.56(.48)$ \\
\hline Pseudo $\mathrm{R}^{\wedge} 2$ & 0.24 & 0.30 & 0.38 \\
\hline
\end{tabular}

Hypothesis 1)) Partisanship has an undeniable relationship with both outcome variables considered in Table 1. At a 99\% significance level, Conservatives are more supportive of unilateral provincial interventions in the City of Toronto than are opposition partisans. The regression results also show that Conservatives are more supportive of the reduction in city council size than opposition partisans. This finding is robust to a control of general support of provincial intervention, as demonstrated by the Council (2) regression results. Collectively, these 
results align with the partisan contamination hypothesis outlined previously. In other words, Conservatives tend to be supportive of reductions in council size and provincial interference in municipal matters, perhaps because these voters associate their partisan group with these policy positions. Meanwhile, opposition partisans who, by definition, do not support the Conservatives are less supportive of policies associated with this partisan group.

The regression results also provide modest evidence that nonpartisans are more supportive of the reduction in city council size than are opposition partisans, at a $95 \%$ significance level. However, there is no evidence that they are more supportive of provincial interventions in municipal matters as compared to opposition partisans. Moreover, when controlling for respondents' general support of provincial intervention in Council (2), there is no longer a significant difference between the attitudes of nonpartisans and opposition partisans towards the reduction in city council size.

Hypothesis 2) The regression results are consistent with the expectations formulated in $\mathrm{H} 2$. Right-leaning individuals are more supportive of the redistricting and provincial intervention as compared to left-leaning individuals at a $99 \%$ significance level. Despite the fact that partisan and ideological attitudes are expected to be closely aligned with one another, these two factors have independent effects. This finding is robust to a control of general support of provincial intervention, as demonstrated by the Council (2) regression results.

Hypothesis 3) Contrary to $\mathrm{H} 3$, there is no observed relationship between people's perceptions about how much the municipal government cares about their opinion and the respondents' level of support for council size reduction or provincial intervention in municipal matters. This finding is unexpected, and is especially surprising when considering that there is a divergence between 
the results of the 'Care' and 'Impact' variables (see H4). Originally, the expectation was that people's perceptions of government responsiveness would align with their perceptions about the municipal government's level of impact in their lives. There is no evidence that this attitude has an independent effect upon opinions of provincial control over Toronto.

Hypothesis 4) The regression results show that as individuals believe the municipal government has a significant impact in their life, they become less supportive of the redistricting and provincial intervention in municipal matters, at a 95\% and 99\% significance levels respectively. These results align with the original expectations. However, when controlling for respondents' support of provincial intervention in municipal matters in Council (2), there is no longer a significant relationship between people's perceptions about the impact of municipal government and their support for city council reduction. In other words, when isolating for the effect of city council reduction more specifically in Council (2), it appears that respondents' attitudes towards unilateral provincial interventions was the driving factor for their opinions in Council (1).

Hypothesis 5) At a 95\% significance level, people who believe that redistricting is an important issue are less supportive of redistricting and less supportive of provincial interference than those who do not believe it is an important issue. This finding is robust to a control of general support of provincial intervention, as demonstrated by the Council (2) regression results. Drawing on the rationale from the original expectations, this result is likely due to the fact that individuals who care about the issue also have a relatively high level of knowledge about the issue as compared to those who do not care. Informed individuals are more likely to understand that redistricting occurred due to provincial interference and are aware of its negative press coverage, including 
concerns about gerrymandering and negative implications for effective representation. Therefore, they are more likely to be against provincial control and redistricting.

Control Variables: While not part of the original hypotheses, it is interesting to note that significant results were observed for all control variables. Older individuals tended to support council reduction and provincial intervention, while women are relatively supportive of provincial intervention (though not of the 2018 redistricting, in particular). The results also indicate that university-educated individuals tend to be relatively unsupportive of both redistricting and council reduction. The place of residence of respondents also matters; individuals living in the city are less supportive of both prompts as compared to those who live in the suburbs. 


\section{CONCLUSION}

The results of this analysis find strong support for $\mathrm{H} 1, \mathrm{H} 2$, and $\mathrm{H} 5$, modest support for H4, and no support for H3. The surprising finding from H3 was that there is no relationship between people's perceptions about how much the municipal government cares about their opinion and the respondents' level of support for either council size reduction or provincial intervention in municipal matters. Before running the Council (2) model, the results in H4 were as expected. However, upon running the Council (2) regression, there was no longer a significant relationship between people's perceptions about the impact of municipal government and their support for city council reduction. These central findings lead to interesting implications about local governance and municipal elections.

One interesting finding is that both Conservatives and opposition partisans may be overemphasizing partisan cues and blindly following their parties rather than assessing policy choices on the basis of merit. Alternatively, it is possible that these partisan groups are not directly reacting to the political parties but are responding to the particular party leader: Doug Ford. For future analysis, it may be useful to include a variable testing attitudes towards Ford to help determine whether attitudes towards the party or the particular candidate are the driving factor in respondent's opinions on the central research questions. Determining this information is important for future political campaigns.

The results from $\mathrm{H} 2$ are especially valuable for candidates. Candidates can use data about citizens' ideological positions to target those groups for campaigns. For example, provincial campaigns that promise greater control over municipal matters are likely to find more support among right-leaning individuals than left-leaning individuals. However, it is important to note that just because right-leaning individuals are more supportive of provincial intervention, it does 
not necessarily mean that left-leaning individuals are not supportive of provincial intervention. In other words, the regression analysis in this paper does not provide evidence to support the idea that provincial interventions are divisive on ideological grounds - there is only evidence to support the claim that right-leaning individuals may be more supportive of campaign promises to increase provincial intervention as compared to left-leaning individuals.

There is room for further research when considering the results of $\mathrm{H} 3$ and H4. It does not appear that people's perceptions of government responsiveness align with their perceptions about the municipal government's level of impact in their lives. Further research could help determine what criteria respondents weigh more heavily when considering the importance of the municipal government's impact on their lives. Further studies may also consider testing attitudes towards provincial intervention in municipal matters in other cities. It is possible that the results from this study are not generalizable to other cities within Canada or cities outside of Canada. It is also interesting to consider other levels of government, such as Canadians' attitudes towards federal interventions in provincial matters, and vice versa.

In addition to studying the generalizability of these findings, there is also further room for deeper investigation in this particular case given that certain themes from the literature review remain unexplored in this study. As mentioned at the outset of this paper, one of the reasons it is important to consider the alignment between public opinion and government policies is to determine if the government is systematically ignoring the voices of certain groups. While addressing this question was not the focus of this paper, future research could consider the alignment between the policy opinions/desires of ethnic minority groups and low-income individuals and how they compare to government action. The results from this proposed study 
could help reveal the nature of the government's response bias and whether marginalized groups are especially adversely affected by the lack of rigorous consultation.

In all, the redistricting in Toronto aligns with the narrative presented in the literature review: the provincial government can intervene at will in municipal matters. This finding is consistent with the information described in the division of powers section, which revealed that municipalities are not a constitutionally entrenched level of government and are effectively "creatures of the province". As such, they can be subjected to provincial changes. The findings of this study are also consistent with provincial disregard for public opinion during the previous restructuring events in Toronto, Winnipeg, Ottawa, Montreal as described in the literature review. Indeed, there appears to be a disconnect between public attitudes and government policy in the case under consideration as evidenced by the fact that the majority of respondents (see pie charts in figure 1) had negative opinions towards provincial control more generally and the specific instance of redistricting. This disconnect between the public opinion and actual public policy suggests low government responsiveness, and points to a problem with Canadian democracy. As such, it is important to consider the trajectory of future changes imposed by provincial governments to determine whether this trend continues. By contributing to the literature and showing that disregard for public opinion is a consistent trend, future studies can serve as a call to action for reform in public consultation to help preserve the legitimacy of Canadian democracy. 
Appendix

\begin{tabular}{|c|c|c|c|}
\hline \multicolumn{2}{|c|}{ Table 1: Summary Statistics } & Mean & Standard Deviation \\
\hline $\begin{array}{l}\text { CouncilSize } \\
\text { Reduction }\end{array}$ & 2216 & 0.422 & 0.406 \\
\hline Unilateral Changes & 2296 & 0.299 & 0.371 \\
\hline Conservative (Y/N) & 2236 & 0.227 & 0.419 \\
\hline Opposition (Y/N) & 2,236 & 0.692 & 0.462 \\
\hline Nonpartisan (Y/N) & 2236 & 0.081 & 0.273 \\
\hline Ideology & 2,301 & 0.457 & 0.241 \\
\hline Municipal Care & 1541 & 0.622 & 0.283 \\
\hline Municipal Impact & 2352 & 0.837 & 0.221 \\
\hline $\begin{array}{l}\text { Municipal } \\
\text { Important }\end{array}$ & 2289 & 0.552 & 0.344 \\
\hline Age & 2268 & 53.987 & 16.873 \\
\hline Gender & 2364 & 0.490 & 0.500 \\
\hline Education & 2373 & 0.630 & 0.483 \\
\hline $\begin{array}{l}\text { Ward (Suburbs vs } \\
\text { Inner-City) }\end{array}$ & 2378 & 0.441 & 0.497 \\
\hline
\end{tabular}




\section{References}

Abelson, J., Gauvin, F., MacKinnon, M. P., \& Watling, J. (2004). Transparency, trust and citizen engagement. Ottawa: Canadian Policy Research Networks Inc.

Achen, Christopher H. (1978). Measuring Representation. American Journal of Political Science pp. $475-510$.

Althaus, Scott L. (2003). Collective Preferences in Democratic Politics. New York: Cambridge University Press.

Arnold, R. D., \& Carnes, N. (2012). Holding mayors accountable: New York's executives from Koch to Bloomberg. American Journal of Political Science, 56(4), 949-963.

Axworthy, L. (1978). The Best Laid Plans Oft Go Astray: The Case of Winnipeg. The Institute of Urban Studies.

Bastien, R. (1981). Federalism and decentralization, where do we stand? (Canada, FederalProvincial Relations). Ottawa: Minister of Supply and Services Canada.

Beckie, M. A., Hanson, L., \& Schrader, D. (2013). Farms or freeways? Citizen engagement and municipal governance in Edmonton's food and agriculture strategy development. Journal of Agriculture, Food Systems, and Community Development,4(1), 15-31.

Bélanger, C. (2001). The Powers of Disallowance and Reservation in Canadian Federalism. Studies on the Canadian Constitution and Canadian Federalism.

Berdahl, L. (2006). The Federal Urban Role and Federal-Municipal Relations. Canada: The State of the Federation 2004. Kingston: Library and Archives Canada. 
Benzie, R. (2017). Kathleen Wynne stopping John Tory's plan for tolls on DVP, Gardiner. Retrieved from https:/www.thestar.com/news/queenspark/2017/01/26/kathleen-wynnestopping-john-torys-plan-for-tolls-on-dvp-gardiner.html.

Beckie, M. A., Hanson, L., \& Schrader, D. (2013). Farms or freeways? Citizen engagement and municipal governance in Edmonton's food and agriculture strategy development. Journal of Agriculture, Food Systems, and Community Development, 4(1), 15-31.

Birch, L., \& Petry, F. (2012). The use of public opinion research by government: insights from American and Canadian research. Chapter, 26, 342-353.

Bird, R. M., \& Tassonyi, A. (2003). Constraining Subnational Fiscal Behavior in Canada: Different Approaches, Similar Results? J. A. Rodden, G. S. Eskeland, \& J. Litvack, F iscal Decentralization and the Challenge of Hard Budget Constraint. Cambridge: Mass.: MIT Press.

Bish, R. L. (2001). Local government amalgamations: discredited nineteenth century ideals alive in the twenty first. Commentary-CD Howe Institute, (150), 1.

Bjørnskov, C., \& Potrafke, N. (2013). The size and scope of government in the US states: does party ideology matter?. International Tax and Public Finance, 20(4), 687-714.

Boudreau, J-A., (2000), The MegaCity Saga: Democracy and Citizenship in This Global Age. Montreal, Canada: Black Rose Books.

Boudreau, J., Hamel, P., Jouve, B., \& Keil, R. (2006). Comparing metropolitan governance: The cases of Montreal and Toronto. Progress in Planning, 66(1), 7-59. doi:10.1016/ j.progress.2006.07.005. 
Boudreau, J., Hamel, P., Jouve, B., \& Keil, R. (2007). New State Spaces in Canada:

Metropolitanization in Montreal and Toronto Compared. Urban Geography, 28(1), 30-53. doi:10.2747/0272-3638.28.1.30.

Bradford, N. J. (2007). Whither the Federal Urban Agenda?: A New Deal in Transition. Ottawa: Canadian Policy Research Networks.

Brody, R., \& Page, B. (1972). Comment: The assessment of policy voting. American Political Science Review, 66(2), 450-458.

Brooks, Clem and Jeff Manza. (2007). Why Welfare States Persist: The Importance of Public Opinion in Democracies. Chicago: University of Chicago Press.

Burstein, Paul. (1998a.) Bringing the Public Back In: Should Sociologists Consider the Impact of Public Opinion on Public Policy? Social Forces 77:27-62.

Burstein, P. (2003).The Impact of Public Opinion on Public Policy: a Review and an Agenda. Political Research Quarterly 56:29-40.

Burstein, P. (2006). Why Estimate of the Impact of Public Opinion on Public Policy Are Too High. Social Forces 94:2273-89.

Burstein, P. (2010). Public Opinion, Public Policy, and Democracy. Handbook of politics: State and society in global perspective. New York: Springer Science Business Media.

Canadian Municipal Election Study / Étude Sur Les Élections Municpales Canadiennes. (n.d.). Retrieved from https://www.cmes-eemc.ca/.

Canada, Ministry of Municipal Affairs and Housing. (2011). BUILDING THE PROVINCIALMUNICIPAL PARTNERSHIP. Ottawa: Ontario Government. 
Calder, M. J., \& Beckie, M. A. (2013). Community engagement and transformation: Case studies in municipal sustainability planning from Alberta, Canada. Community Development, 44(2), 147-160. http://dx.doi.org/10.1080/15575330.2012.705868.

Cairns, Alan C. (1977). The Governments and Societies of Canadian Federalism. Canadian Journal of Political Science 10(4): 695-726.

Consolidated Municipal Service Manager (CMSM) inter-municipal social program cost sharing. (n.d.). Retrieved 2016, from https://www.ontario.ca/data/consolidated-municipalservice-manager-cmsm-inter-municipal-social-program-cost-sharing.

Crawley, M. (2016). Tolls in Toronto: Wynne's Liberals could pay a heavy price |CBC News. Retrieved from https:/www.cbc.ca/news/canada/toronto/tolls-gardiner-dvp-torontokathleen-wynne-john-tory-1.3865516.

Crawley, M. (2017). Why Kathleen Wynne is putting the brakes on Toronto tolls $\mid$ CBC News. Retrieved from https://www.cbc.ca/news/canada/toronto/kathleen-wynne-john-toryroad-tolls-gardiner-dvp-1.3955264.

Constitution Act, 1867 (UK), 30 \& 31 Vict, c 3, s 91, reprinted in RSC 1985, Appendix II, No 5. Constitution Act, 1982, s 35, being Schedule B to the Canada Act 1982 (UK), 1982, c 11.

Collins, P. A., Power, E. M., \& Little, M. H. (2014). Municipal-level responses to household food insecurity in Canada: a call for critical, evaluative research. Can J Public Health, 105(2), e138-41.

Cooper, P. J., \& Vargas, C. M. (2004). Implementing sustainable development: From global policy to local action. Lanham, Maryland: Rowman \& Littlefield.

Côté, A., \& Fenn, M. (2014). Provincial-Municipal Relations in Ontario: Approaching an In! ection Point. Institute on Municipal Finance and Governance. 
Cutler, Fred. (2004). Government Responsibility and Electoral Accountability in Federations. Publius: The Journal of Federalism 34(2): 19-38.

Courcene, T. (2006). Citistates and the State of Cities: Political Economy and Fiscal-Federal Dimensions. Canada: The State of the Federation 2004. Kingston: Library and Archives Canada.

Courchene, T. J. (2007). Global Futures for Canadas Global Cities (Vol. 8). Montréal: Institute for Research on Public Policy.

Dalton, R. J., Burklin, W. P., \& Drummond, A. (2001). Public opinion and direct democracy. Journal of Democracy, 12(4), 141-153.

D'Amore, R., \& Fox, C. (2017). Wynne says no to Toronto road tolls, instead doubles gas tax given to municipalities for transit. Retrieved from https:// toronto.ctvnews.ca/wynne-says-no-to-toronto-road-tolls-instead-doubles-gas-tax-givento-municipalities-for-transit-1.3259508.

Department of Finance. Budget 2005: A New Deal for Canada's Communities. Budget 2005: A New Deal for Canada's Communities, 24 Feb. 2005, fin.gc.ca/budget05/pamph/pacomeng.asp.

Dewing, M., Young, W., and Tolley, E. (2006). Municipalities, the Constitution, and the Canadian Federal System. Ottawa: Library of Parliament.

Downs, William M. (1999). Accountability Payoffs in Federal Systems? Competing Logics and Evidence from Europe's Newest Federation. Publius: The Journal of Federalism 29 (1): $87-110$. 
Erikson, Robert S. Gerald C. Wright, and John P. McIver. (1993). Statehouse Democracy. New York: Cambridge University Press.

Fording, Richard C. 1997. The Conditional Effect of Violence as a Political Tactic: Mass Insurgency, Welfare Generosity, and Electoral Context in the American States. American Journal of Political Science 41:1-29.

Erikson, Robert S., Michael B. MacKuen, and James A. Stimson. (2002). The Macro Polity. New York: Cambridge University Press.

Extended Producer Responsibility (EPR) Programs in BC. (2018). Retrieved from https:// www.rcbc.ca/recycling-programs/epr.

Field, M. A. (1992). The differing federalisms of Canada and the United States. Law and Contemporary Problems, 55(1), 107-120.

Filipowicz, J. (2018, August 01). Fewer elected officials-not a good way for Toronto City Hall to save money: Op-ed. Retrieved from https://www.fraserinstitute.org/article/fewer-electedofficials-not-a-good-way-for-toronto-city-hall-to-save-money.

Forrester, J. (2009). Improved partnership working for local authority transport planning. European Journal of Transport and Infrastructure Research, 9(3), 314-330. http:// www.ejtir.tudelft.nl.

Fyfe, Stewart. (1975). Local Government Reform in Ontario. R. Charles Bryfogle and Ralph R. Krueger, eds., Urban Problems Revised. Toronto: Holt, Rinehart and Winston of Canada. 
Geoffrey Evans \& Robert Andersen (2004) Do issues decide? Partisan conditioning and perceptions of party issue positions across the electoral cycle, British Elections \& Parties Review, 14:1, 18-39.

Goodyear-Grant, Elizabeth and Anderson, Cameron D. (2006). Conceptions of Political Representation in Canada: An Explanation of Public Opinion. Canadian Journal of Political Science 38(4): 1029-58.

Goren, P. (2005). Party identification and core political values. American Journal of Political Science, 49(4), 881-896.

Graham, K. A., Maslove, A. M., \& Phillips, S. D. (2001). Learning from experience? Ottawa as a cautionary tale of reforming Urban government. Journal of Comparative Policy Analysis: Research and Practice, 3(3), 251-269. doi:10.1080/13876980108412662.

Gray, J. (2018). Province had no duty to consult before cutting Toronto council size, lawyers argue. Retrieved from https://www.theglobeandmail.com/canada/article-province-hadno-duty-to-consult-before-cutting-toronto-council-size/.

Gray, J. (2018). Judge mulls Premier Ford's cut to Toronto council. Retrieved from https:// www.theglobeandmail.com/canada/toronto/article-judge-in-case-against-fords-cut-totoronto-council-has-open-mind/.

Gutstein, Donald. (1983). "Vancouver," City Politics in Canada, eds. Warren Magnusson and Andrew Sancton. Toronto: University of Toronto Press, 1983.

Harrison, T. M., Guerrero, S., Burke, G. B., Cook, M., Cresswell, A., Helbig, N.,. \& Pardo, T. (2012). Open government and e-government: Democratic challenges from a public value perspective. Information Polity, 17(2), 83-97.

Healey, P. (2003). Collaborative planning in perspective. Planning Theory, 2(2), 101-123. 
http://dx.doi.org/10.1177/14730952030022002

Healey, P. (2012). Re-enchanting democracy as a mode of governance. Critical Policy Studies, 6(1), 19-39. http://dx.doi.org/10.1080/19460171.2012.659880.

Howe, Paul, Richard Johnston, and Andre Blais, eds. (2005). Strengthening Canadian Democracy. Montreal: Institute for Research on Public Policy.

Inglehart, R., \& Klingemann, H.-D. (1976). Party identification, ideological preference, and the left-right dimension among Western mass publics. I. Budge, I. Crew, \& D. Farlie (Eds.), Party identification and beyond. New York: Wiley.

Innes, J. (1995). Planning theory's emerging paradigm: Communicative action and interactive practice. Journal of Planning Education and Research, 14(3), 183- 189. http://dx.doi.org/ 10.1177/0739456X9501400307.

Innes, J. E., \& Booher, D. E. (2004). Reframing public participation: Strategies for the 21 st century. Planning Theory \& Practice, 5 (4), 419-436. http://dx.doi.org $10.1080 / 1464935042000293170$.

Inwood, G. J., Johns, C. M., \& OReilly, P. L. (2011). Intergovernmental policy capacity in Canada inside the worlds of finance, environment, trade, and health. Montréal: McGillQueens Univ. Press.

Inwood, G. J. (2013). Understanding Canadian federalism: An introduction to theory and practice. Toronto: Pearson Canada.

Jacobs, L. R., \& Shapiro, R. Y. (2005). Polling politics, media, and election campaigns: Introduction. The Public Opinion Quarterly, 69(5), 635-641. 
Jou, W., \& Dalton, R. J. (2017). Left-Right Orientations and Voting Behavior. Oxford Research Encyclopedia of Politics. doi:10.1093/acrefore/9780190228637.013.581.

Keenan, E. (2018). Doug Ford's attack on Toronto's city council is a declaration of war. Retrieved from https://www.thestar.com/opinion/star-columnists/2018/07/27/fordsmove-to-slash-toronto-council-without-consultation-an-undemocratic-move.html.

Key, V. O., Jr., (1961). Public Opinion and American Democracy. New York: Knopf.

Keil, R., \& Young, D. (2003). A charter for the people? A research note on the debate about municipal autonomy in Toronto. Urban Affairs Review, 39(1), 87-102.

KPMG Canada. Fresh Start: An Estimate of Potential Savings and Costs from the Creation of Single Tier Local Government for Toronto. Toronto: KPMG Canada, 16 December 1996.

Kushner, J., \& Siegel, D. (2003). Citizens' attitudes toward municipal amalgamation in three Ontario municipalities. Canadian Journal of Regional Science, 26(1), 49-62.

Lapointe, Jean-Louis. (1980). La reforme de la fiscalite municipale au Quebec. Canadian Public Administration.23(2); 269-80.

Lazar, H., \& Seal, A. (2005). Local government: Still a junior government? The place of municipalities within the Canadian federation. In The place and role of local government in federal systems. Johannesburg: Konrad-Adenauer-Stiftung.

Levine, R. (2018). U of T experts on what Doug Ford's proposed changes to city council mean for Toronto. Retrieved from https://www.utoronto.ca/news/u-t-experts-what-doug-ford-sproposed-changes-city-council-mean-toronto'. 
Lorinc, J. (2018). LORINC: What does 'effective representation' look like at city hall? Retrieved from http://spacing.ca/toronto/2018/09/04/lorinc-what-does-effective-representationlook-like-at-city-hall/.

Macdonald, R. The Political Economy of the Federal Spending Power'(2008). Queen's Law Journal, 34, 249.

Manza, J., \& Cook, F. L. (2002). A democratic polity? Three views of policy responsiveness to public opinion in the United States. American Politics Research, 30(6), 630-667.

Mallory, J. R. (1981). Conflict Management in the Canadian Federal System. Law and Contemporary Problems, 44(3), 231-246.

Manza, Fay Lomax Cook, and Benjamin I. Page. New York: Oxford University Press.

Marland, A., Giasson, T., \& Lees-Marshment, J. (Eds.). (2012). Political marketing in Canada. UBc Press.

Masuda, J. R., McGee, T. K., \& Garvin, T. D. (2008). Power, knowledge, and public engagement: Constructing “citizenship” in Alberta's industrial heartland. Journal of Environmental Policy \& Planning, 10(4), 359-380.

McAllister, M. L.(2014). Governing Ourselves? The Politics of Canadian Communities. Vancouver: UBC Press.

McAllister, Mary Louise. (2004). Governing Ourselves? The Politics of Canadian Communities. Vancouver: UBC Press.

McCann, E. J. (2001). Collaborative visioning or urban planning as therapy? The politics of public-private policy making. Professional Geographer, 53(2), 207-218. http:// dx.doi.org/10.1111/0033-0124.00280. 
McGregor, R. M., Moore, A. A., \& Stephenson, L. B. (2016). Political Attitudes and Behaviour in a Non-Partisan Environment: Toronto 2014. Canadian Journal of Political Science, 49(02), 311-333. doi:10.1017/s0008423916000573.

Meekison, J. P., Telford, H., \& Lazar, H. (2004). Reconsidering the institutions of Canadian federalism. Montreal: McGill-Queens University Press.

Miljan, L. A., \& Spicer, Z. (2015). De-Amalgamation In Canada: Breaking up is hard to do. Fraser Institute..

Mintz, E., Croci, O., \& Close, D. (2019). Politics, power and the common good: An introduction to political science. Toronto: Pearson.

Monroe, Alan. (1979). Consistency between Constituency Preferences and National Policy Decisions. American Politics Quarterly 12(1): 3- 19.

Moore, A. A., McGregor, R. M., \& Stephenson, L. B. (2017). Paying attention and the incumbency effect: Voting behavior in the 2014 Toronto Municipal Election. International Political Science Review, 38(1), 85-98.

Nabatchi, T. (2010). Addressing the citizenship and democratic deficits: The potential of deliberative democracy for public administration. The American Review of Public Administration, 40(4), 376-399.

Nader, George A. (1976). Winnipeg. Cities of Canada, Volume Two: Profiles of Fifteen Metropolitan Centres. Toronto: Macmillan of Canada. Maclean-Hunter Press.

Page, Benjamin I. and Robert Y. Shapiro. (1983). Effects of Public Opinion on Policy. American Political Science Review 77 (Mar.): 175-90. 
Page, B. I. (2002). The semi-sovereign public. Navigating public opinion: Polls, policy, and the future of American democracy, 325-44.

O’Brien, Allan. (1975). A. Father Knows Best: A Look at the Provincial-Municipal.

Relationship in Ontario. Donald C. MacDonald (ed.), Government and Politics of Ontario. Toronto: Macmillan.

Ontario. Committee on Taxation. (1967). Report.Toronto: Queen's Printer

Oved, M. C. (2018). How does the urban-suburban divide play out in a 25-seat Toronto council? Retrieved from https://www.thestar.com/news/city_hall/2018/07/28/how-does-the-urbansuburban-divide-play-out-in-a-25-seat-toronto-council.html.

Oved, M. C. (2018). How does the urban-suburban divide play out in a 25-seat Toronto council? Retrieved from https://www.thestar.com/news/city hall/2018/07/28/how-does-the-urban$\underline{\text { suburban-divide-play-out-in-a-25-seat-toronto-council.html. }}$

Pigeon, L. P. (1951). The Meaning of Provincial Autonomy. Can. B. Rev., 29, 1126.

Pagliaro, J. (2018). City of Toronto argues province 'meddled' in election with unprecedented cut to council. Retrieved from https:/www.thestar.com/news/toronto-election/2018/08/28/ city-of-toronto-argues-province-meddled-in-election-with-unprecedented-cut-tocouncil.html.

Pearce, W. B., \& Littlejohn, S. W. (1997). Moral conflict: When social worlds collide. Thousand Oaks, California: SAGE.

Pelley, L. (2018). Province intends to argue municipalities are 'creatures of the legislature' amid council cuts legal battle | CBC News. Retrieved from https:/www.cbc.ca/news/canada/ toronto/province-intends-to-argue-municipalities-are-creatures-of-the-legislature-amidcouncil-cuts-legal-battle-1.4803637. 
Pelley, L. (2018). How critics plan to challenge Doug Ford's council-cutting bill in court on Friday $\mid$ CBC News. Retrieved from https://www.cbc.ca/news/canada/toronto/howcritics-plan-to-challenge-doug-ford-s-council-cutting-bill-in-court-on-friday-1.4800556.

Petry, F. (2007). How policy makers view public opinion. Policy analysis in Canada: The state of the art, 375-398.

Petry, Francois. (1999). The Opinion-Policy Relationship in Canada. Journal of Politics 61(2): 540-50.

Petry, Francois and Matthew Mendelsohn. (2004). Public Opinion and Policy Making in Canada, 1995-2001. Canadian Journal of Political Science 27 (3): 505-29.

Press, J. (2017). Big cities home to big share of 35 million Canadians $\mid$ CBC News. Retrieved from https://www.cbc.ca/news/politics/cities-population-census-2016-1.3972062.

Rieti, J. (2018). Doug Ford's shocking council cut pits longtime councillors against one another | CBC News. Retrieved from https://www.cbc.ca/news/canada/toronto/doug-ford-plansets-up-council-fight-1.4764902.

Rosenfeld, R. A., \& Reese, L. A. (2003). The Anatomy of an Amalgamation: The Case of Ottawa. State and Local Government Review, 35(1), 57-69. doi:10.1177/0160323x0303500106.

Roseland, M. (2005). Toward sustainable communities:Resources for citizens and their governments (Revised ed.). Gabriola Island, British Columbia: New Society.

Rydin, Y., \& Pennington, M. (2000). Public participation and local environmental planning: The collective action problem and the potential of social capital. Local Environment, 5(2), 153-169. http://dx.doi.org/10.1080/13549830050009328.

Sancton, Andrew. (1993). Policymaking for Urban Development in American and Canadian Metropolitan Regions. Metropolitan Governance: American/Canadian 
Intergovernmental Perspectives, eds. Donald N. Rothblatt and Andrew Sancton. Berkley: Institute of Governmental Studies Press: 1-12.

Sancton, Andrew. (2002). Municipalities, Cities and Globalization: Implications for

Canadian Federalism. In Bakvis and Skogstad. 261-277.

Sancton, Andrew. (1993). Policymaking for Urban Development in American and

Canadian Metropolitan Regions. Metropolitan Governance: American/Canadian

Intergovernmental Perspectives, eds. Donald N. Rothblatt and Andrew Sancton. Berkley: Institute of Governmental Studies Press: 1-12.

Sancton, A. (1995). Governing Canadas city regions: Adapting form to function. Montreal, Quebec: Inst. for Research on Public Policy.

Sancton, A. (2000). Amalgamations, Service Realignement and Property Taxes: Did the Harris Government Have a Plan for Ontario's Municipalities?. Canadian Journal of Regional Science, 23(1), 135-156.

Sancton, Andrew (2006). Municipal Mergers and De-Mergers in Quebec and Ontario. Presented at the Annual Meeting of the Canadian Political Science Association, York University, Toronto, Ontario.

Sancton, Andrew (2011). Canadian Local Government: An Urban Perspective. Oxford University Press.

Sancton, A. (2001). Canadian Cities and the New Regionalism. Journal of Urban Affairs, 23(5), 543-555. doi:10.1111/0735-2166.00105.

Schwartz, H. (2009). Toronto Ten Years after Amalgamation. Canadian Journal of Regional Science. 
Scott, F. (1951). Centralization. and Decentralization in Canadian Federalism. The Canadian Bar Review, 29(10).

Schrefler, L. (2010). The Usage of Scientific Knowledge by Independent Regulatory Agencies. Governance: An International Journal of Policy, Administration and Institutions, 23(2): 309-330.

Seidle, F. Leslie. (2007). Citizens Speaking for Themselves: New Avenues for Public Involvement. Political Leadership and Representation in Canada: Essays in Honour of John C. Courtney, eds. Hans J. Michelmann, Donald C. Story, and Jeffrey S. Steeves, 81-109. Toronto: University of Toronto Press.

Sharman, C. (1984). The Strange Case of a Provincial Constitution: The British Columbia Constitution Act. Canadian Journal of Political Science, 17(1), 87-108. doi:10.1017/ S000842390005127

Shapiro, R. Y. (2011). Public opinion and American democracy. Public Opinion Quarterly, 75(5), 982-1017.

Shum, D. (2017). Toronto mayor fumes at being treated like 'little boy' after Ontario nixes road tolls plan. Retrieved from https://globalnews.ca/news/3209418/ontario-premier-slamsbrakes-on-tolls-for-dvp-gardiner/.

Siegel, David. (1997). Local Government in Ontario. The Government and Politics of Ontario, eds. Graham White. Toronto: University of Toronto Press: 126-157.

Siegel, D. (2006). Recent Changes in Provincial-Municipal Relations in Ontario: A New Era or a Missed Opportunity. In Canada: The State of the Federation 2004. Kingston: Queen's University. 
Siegel, David. (1997). Local Government in Ontario. The Government and Politics of Ontario, eds. Graham White. Toronto: University of Toronto Press: 126-157.

Simeon, R. (2002). Federalism and decentralization in Canada. In 2nd International Conference on Decentralization, Manila.

Simeon and Papillon (2006). The division of powers in Canada: an overview.

Simeon, Richard, and David Cameron. (2002). Federalism and Democracy: An Oxymoron if Ever There Was One? In Canadian Federalism, eds. Herman Bakvis and Grace Skogstad, 278-95. Toronto: Oxford University Press.

Slack, E., \& Bird, R. M. (2006). Cities in Canadian federalism. Institute on Municipal Finance and Governance, Munk School of Global Affairs.

Slack, E. (2009). Provincial-Local Fiscal Transfers in Canada: Provincial Control Trumps Local Accountability. Munk Centre for International Studies.

Slack, E., \& Bird, R. (2013). Does Municipal Amalgamation Strengthen the Financial Viability of Local Government? A Canadian Example. International Center for Public Policy.

Slack, Enid and Richard Bird. (2013). Merging Municipalities: Is Bigger Better? IMFG Papers on Municipal Finance and Governance No. 14. Toronto: Institute on Municipal Finance and Governance, University of Toronto.

Smith, D. K. (2007). Inter-municipal collaboration through forced amalgamation: A summary of recent experiences in Toronto \& Montreal. Project on New Public Consortia for Metropolitan Governance (NPC Project), Vancouver, 14-19.

Smith, Lancelot J. (1967). The Ontario Committee on Taxation - Report VI. Toronto: Queen's Printer. Government of Ontario. 
Spicer, Zachary. (2013). Regional Organization and the Dynamics of Inter-Municipal

Cooperation. Electronic Thesis and Dissertation Repository. 1312.

Spicer, Zachary. (2014). Linking Regions, Linking Functions. Inter-Municipal

Agreements in Canada. IMFG Perspectives 10. Toronto: Institute on Municipal Finance and Governance, University of Toronto. December 2014.

Spicer, Zachary. (2013). Regional Organization and the Dynamics of Inter-Municipal

Cooperation. PhD Thesis: University of Western Ontario, Department of Political

Science.

Spicer, Zachary (2014). Too Big, Yet Still Too Small: The Mixed Legacy of the Montreal and Toronto Amalgamations. IMFG Perspectives 5. Institute on Municipal Finance and Governance, Munk School of Global Affairs, University of Toronto.

Spicer, Z. (2014). The Ties That Bind? Exploring the Dynamics of Intermunicipal Agreement Formation between Separated Cities and Counties. Canadian Public Policy, 40(3), 245-258. doi:10.3138/cpp.2013-051.

Spicer, Z. (2015). Cooperation and capacity: inter-municipal agreements in Canada. Institute on Municipal Finance and Governance.

Spicer, Z. (2016). A Patchwork of Participation: Stewardship, Delegation and the Search for Community Representation in Post-Amalgamation Ontario. Canadian Journal of Political Science, 49(01), 129-150. doi:10.1017/s0008423916000275.

Spicer, Z. (2011). The Rise and Fall of The Ministry of State For Urban Affairs: A ReEvaluation. Canadian Political Science Review, 5. 
Spicer, Z. (2015). Regionalism, Municipal Organization, and Interlocal Cooperation in Canada. Canadian Public Policy, 41(2), 137-150.

Statistics Canada. (2017). Focus on Geography Series, 2016 Census. Retrieved from https:// www12.statcan.gc.ca/census-recensement/2016/as-sa/fogs-spg/Facts-cma-eng.cfm? $\mathrm{LANG}=$ Eng $\& \mathrm{GK}=\mathrm{CMA} \& \mathrm{GC}=535 \&$ wbdisable $=$ true.

Statistics Canada. (2018). Canada goes urban. Retrieved from https://www150.statcan.gc.ca/n1/ pub/11-630-x/11-630-x2015004-eng.htm.

Statistics Canada. (2015). Section 1: Census metropolitan areas. Retrieved from https:// www150.statcan.gc.ca/n1/pub/91-214-x/2015000/section01-eng.htm.

Stevenson, G. (2004). Unfulfilled union: Canadian federalism and national unity. Montreal: McGill-Queens University Press.

Steytler, N. (Ed.). (2005). The place and role of local government in federal systems. KonradAdenauer-Stiftung.

Stoney, C., \& Graham, K. A. (2009). Federal-municipal relations in Canada: The changing organizational landscape. Canadian Public Administration, 52(3), 371-394. doi:10.1111/ j.1754-7121.2009.00088.x.

Soroka, S., \& Wlezien, C. (2010). Public opinion and public policy. The Oxford Handbook of Canadian Politics, 263.

Soroka, S. N., \& Wlezien, C. (2010). Degrees of democracy: Politics, public opinion, and policy. Cambridge University Press.

Soroka, Stuart N., and Elvin T. Lim. (2003). Issue Definition and the Opinion-policy Link: Public Preferences and Health Care Spending in the US and UK. British Journal of Politics and International Relations 5:576-93. 
Soroka, Stuart N., and Christopher Wlezien. (2005). Opinion-Policy Dynamics: Public

Preferences and Public Expenditure in the United Kingdom. British Journal of Political Science 35:665-89.

Spicer, Z. D. (2012). The rise and fall of the Ministry of State for Urban Affairs: Exploring the nature of federal-urban engagement in Canada. Canadian Political Science Review, 5(2), 117-126.

Stimson, James A., Michael B. MacKuen, and Robert S. Erikson. (1995). Dynamic Representation. American Political Science Review 89: 543-65.

Tassonyi, Almos. (1994). Municipal Debt Limits and Supervision: The 1930s and 1990s in Ontario. Government and Competitiveness Discussion Paper Series. Kingston: Queen's School of Policy Studies.

Tausanovitch, C., \& Warshaw, C. (2014). Representation in municipal government. American Political Science Review, 108(3), 605-641.

The State of Canada's Cities and Communities 2012 (Rep.). (2012). Ottawa: Federation of Canadian Municipalities.

Tindal, Richard and Susan Nobes Tindal. (2004). Local Government in Canada. Toronto: Thomson Nelson.

Troilo, M. (2013). THE WELFARE STATE AFTER THE SECOND WORLD WAR: A COMPARISON BETWEEN ITALY AND CANADA (1945-2013). Sæculum-Revista de História, (29).

Trosow, S. E. (2019). Fighting Doug Ford's threat to shrink Toronto city council. Retrieved from https://theconversation.com/fighting-doug-fords-threat-to-shrink-toronto- 
city-council-100798.

Trudeau, Pierre Elliott. (1968). Federalism and the French Canadians. Toronto: Macmillan. Vaillancourt, François, and Jean-Philippe Meloche (2013). Public Finance in Montréal: In Search of Equity and Efficiency. IMFG Papers 15. Institute on Municipal Finance and Governance, Munk School of Global Affairs, University of Toronto.

Watts, Ronald L, and Douglas M. Brown. (1990). Canada: The State of the Federation, 1990. Kingston: Institute of Intergovernmental Relations, Queen's University.

Whitzman, Carolyn and Tom Slater. (2006). Village Ghetto Land: Myth, Social Conditions and Housing Policy in Parkdale, Toronto, 1879-2000, Urban Affairs Review 41.

Wichern, P. (1986). Evaluating Winnipeg's Unicity: The City of Winnipeg Act Review Committee, 1984-1986. The Institute of Urban Studies, (26).

Wlezien, C. (1995). The public as thermostat: Dynamics of preferences for spending. American Journal of Political Science, 39, 981-1000.

Wlezien, Christopher. (2004). Patterns of Representation: Dynamics of Public Preferences and Policy. Journal of Politics 66:1-2.

Yalnizyan, A. (2018). Toronto's Economy Doesn't get the Respect it Deserves. Retrieved from https://www.macleans.ca/economy/economicanalysis/torontos-economy-doesntgetthe-respect-it-deserves/.

Zhenming Chen, Deguo Li \& Jing Wang (2010) Citizens' Attitudes Toward Local Government Public Services, Public Performance \& Management Review, 34:2, 221-235. 
Zaller, John R. (1992). The Nature and Origins of Mass Opinion. New York: Cambridge University Press. 